\title{
A gravetti telepek topográfiája
}

\author{
T. Dobosi Viola, Holl Balázs
}

Kivonat

\section{Abstract}

\section{Kulcsszavak}

Keywords

\section{Szerző • Author}

Hivatkozás • Cite as

Kézirat történet • Article history

Jogok • Copyright (c) (i) $(8)$

\begin{abstract}
A gravetti entitás három kronológiai szintje és a kapcsolódó három kulturális fílum (idősebb pengés/pavlovi, az utódjának tekinthető fiatalabb pengés/epigravetti és a részben kortárs ságvári) topográfiáját vizsgáljuk a következő lelőhelyek kapcsán. Pavlovi: Bodrogkeresztúr-Henye, Megyaszó-Szeles-tető, Hont-Parassa III./Orgonás, Nadap-Kőbánya, (Püspökhatvan: speciális funkciójú telep, a helyválasztást döntően a nyersanyag-forrás határozta meg). Epigravetti: Pilismarót, Jászfelsőszentgyörgy-Szúnyogos, Esztergom-Gyurgyalag, (Arka-Herzsarét: Vértes L. interpretálásában vegyes, általános és speciális funkciójú telep, a helyválasztást részben a nyersanyagforrás határozta meg). Ságvári: Ságvár-Lyukas-domb, Madaras-Téglavető, Mogyorósbánya Újfalusi dombok. A negyedik, jégkorvégi kronológiai szintet Arka és Pilismarót-Bánom felső kultúrrétege képviseli. Arka felső kultúrrétegre ugyanaz érvényes, mint az alsóra, Pilismarót-Bánom lelőhelyen előkerült néhány eszköz csak sztratigráfiai bizonyíték, minden közelebbi adat, kísérő lelet nélkül. A három kulturális fílumot összehasonlítjuk a tipológia, a nyersanyag valamint a metrikus értékek szempontjából is.
\end{abstract}

\section{Topography of Gravettian sites}

We are investigating the topography of Gravettian sites in Hungary, with the distinction of three chronological stages and related cultural phyla of this entity (older leptolithic / Pavlovian, younger leptolithic /Epigravettian, and the pene-contemporeous Ságvárian). The investigated Hungarian sites are: Bodrogkeresztúr-Henye, Megyaszó-Szeles-tető, Hont-Parassa III./Orgonás, Nadap-Kőbánya, Püspökhatvan (Pavlovian); Pilismarót, Jászfelsőszentgyörgy-Szúnyogos, Esztergom-Gyurgyalag, Arka-Herzsarét (Epigravettian); Ságvár-Lyukas-domb, Madaras-Téglavetố, Mogyorósbánya Újfalusi dombok (Ságvárian).

A fourth chronological stage is represented by the upper cultural layers of Arka and Pilismarót-Bánom. At the former site, the upper layer contains similar material as the lower. At Pilismarót-Bánom, the upper layer contained only a handful of cultural material, serving as stratigraphical clues only.

The typology, raw material and metrics of the three cultural phyla are compared.

Gravetti entitás, pavlovi, epigravetti, ságvári, topográfia

Gravettian entity, Pavlovian, Epigravettian, Ságvárian, topography

T. Dobosi Viola, Magyar Nemzeti Múzeum, 1088 Budapest, Múzeum krt. 14-16.

Holl Balázs, Magyar Nemzeti Múzeum, 1088 Budapest, Múzeum krt. 14-16.

T. Dobosi, V., Holl, B. (2013) A gravetti telepek topográfiája. (Topography of Gravettien sites) Litikum 1:73-88. https://doi.org/10.23898/litikuma0006

Érkezés | Received: 20123 10. 10. Elfogadás | Accepted: 2013. 10. 15. Közzététel | Published: 2013. 12. 10.

(C) Az egyes szerző(k). Ez egy nyílt hozzáférésű publikáció, amit a Creative Commons 4.0 licensze véd. A termék szabadon használható, terjeszthető és sokszorosítható az eredeti szerző és forrás megjelölése mellett. | This is an open-access article distributed under the terms of the Creative Commons Attribution License, which permits unrestricted use, distribution, and reproduction in any medium, provided the original author and source are credited.

\section{Bevezetés}

A jégkorszak utolsó 15 ezer évét az egyre gyorsuló ütemú éghajlati ingadozások következményeként az élő és élettelen környezet kis mértékű, gyors változása jellemzi. Az ezekhez az ökológiai adottságokhoz való sikeres alkalmazkodás Közép- és Kelet-Európában sok tekintetben egységes anyagi és szellemi kultúrát eredményezett. Az egymáshoz mozaikosan illeszkedő helyi színezetû́ kulturális egységek összessége, a gravetti entitás élettartama jól meghatározható: a felső paleolitikum középső (Middle Upper Paleolithic) és késői (Late Upper Paleolithic) szakasza, 26-28 ezer évtől a jégkorszak végéig. Az idôrendi kereteken kívül az elnevezés jogosságának több olyan ismérve van, ami egyelőre nálunk hiányzik. Pl. a vállas hegy, ami előfordul a Dontól Morvaországig (a Hidasnémeti-Borház-dűlôn előkerült vállas hegy nem
Kostienki típusú, Simán 1989). Egyelőre hiányoznak a bázistelepek, az azokra jellemző struktúrák, jelenségek: 1) félig földbe mélyített vagy földfelszíni, tartós építmények (Kelet- és Közép-Európában mamutcsont-kunyhók, Kelet-Európában hosszúházak, szárnyékok, esetleg kemencék?, hústároló vermek); 2) mobil múvészeti alkotások; 3) temetkezések; 4) gazdag csontipar.

A gravetti közösséghez tartozást erősíti a települések helyének megválasztásánál érvényesülő azonos elv, a települések belső szerkezetének hasonlósága, a hazai lelő-helyek eszközkészletében előforduló Gravette-hegy, mint fossile directeur, az eszköztípusok közelítően azonos aránya, luxustárgyak (borostyán, ékszercsigák) stb. A Kárpát-medence lelőhelyei a helyi, regionális és nagy távolságokból beszerzett nyersanyagok gazdag választékával színesítik a gravetti tablót. 


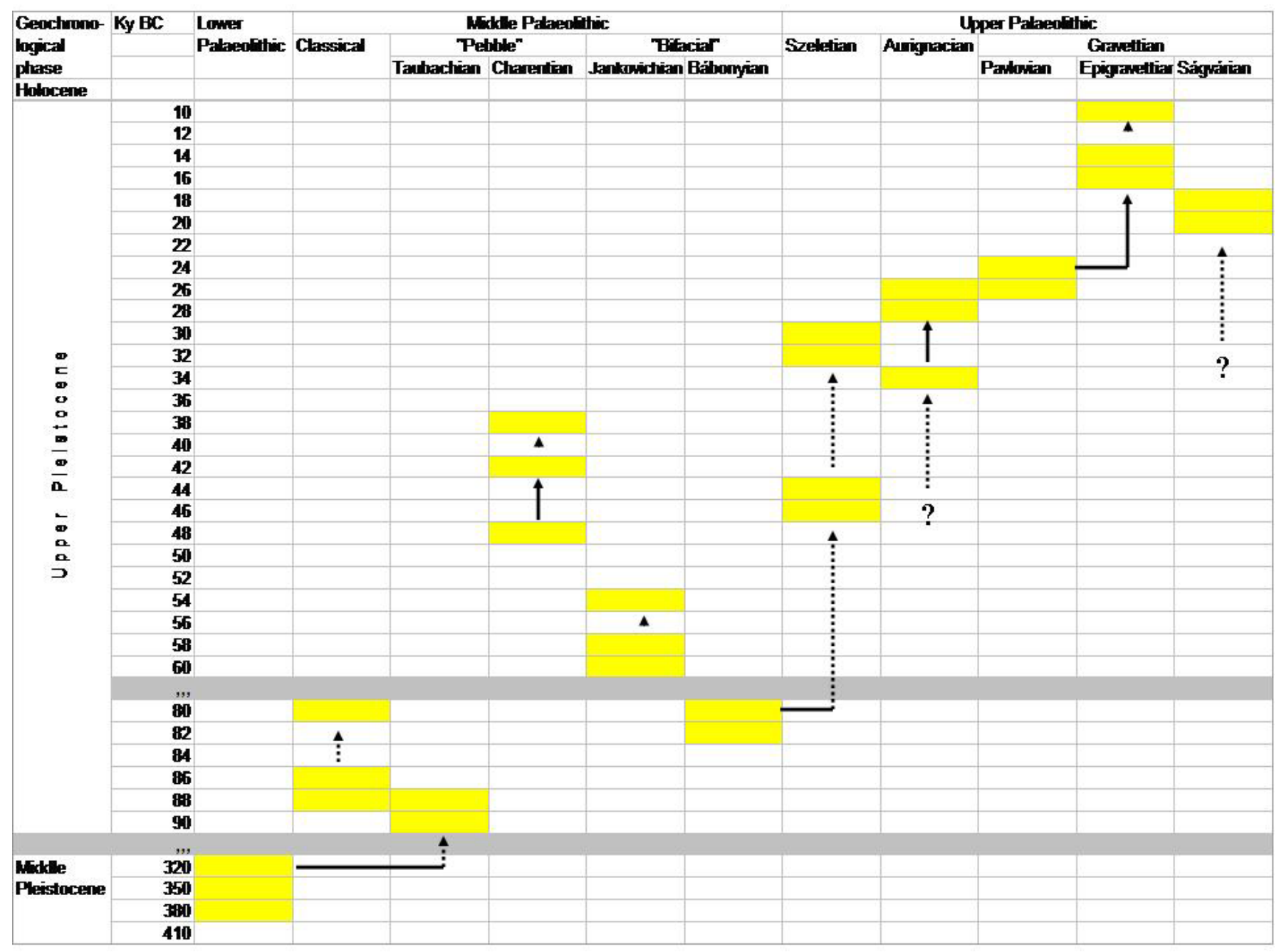

1. ábra. A hazai felső paleolitikum időrendje. // Figure 1. Chronology of the Hungarian Upper Palaeolithic.

Magyarországon ebből az időszakból két, egymással vélhetően genetikai kapcsolatban álló pengés (pavlovi és epigravetti), és az epigravettivel részben egyidős, ám egy-előre ismeretlen eredetû és kapcsolatrendszerü, kavics-alapú kultúra, a ságvári telepeit ismerjük (1. ábra).

Egy topográfiailag jól körülhatárolt lelőhelycsoport nevéből a pavlovi mára a gravetti kultúrkör idősebb szakaszának (3025 ezer év BP) Közép-Európában érvényes elnevezésévé bővült. Így a gravetti entitás idősebb pengés kultúrájának hazai lelőhelyeire is érvényes. Bár Magyarország nem tartozott a korszak kulturális centrumai közé, a kultúra közép-európai megjelenésének legkorábbi szakaszában Magyarország északi sávjában is megjelennek a telepei.

A késő glaciális hidegcsúcs (LGM), az Európában általánosan elfogadott 20 ezer év BP utáni időszak a késői felső paleolitikum (LUP). A hazai kutatók a rétegtani-őslénytani adatok, a történeti események és az időrend összehangolásában még nem jutottak egységes álláspontra. Nehézségek vannak a mikro- és makrofaunában gazdag barlangi, és a fajszegény nyílt színi lelőhelyek rétegsorának összehangolásában. Még nem bizonyítható egyértelmúen az LGM körüli időpontokra datált nyílt színi telepek geokronológiai helyzete (közvetlenül előtte?, alatta?, szerintem utána). A nyugat-európai kronológia és terminológia átvételénél nem hagyható figyelmen kívül a Kárpátoknak a klimatikus események hatását mérséklő vagy késleltető, napjainkban is érzékelhető szerepe.

Az epigravetti fílum a gravetti életvitel és az eszközmegmunkálás hagyományainak megőrzésével a pavlovi kultúra örökösének tekinthető. A kis mobil közösségek rövid ideig lakott telepei az egész országban megtalálhatók.

Ugyancsak a Würm utolsó hidegcsúcsát követő (?) interstadiális(ok) alatt élt a kavics gravetti vagy ságvári kultúra. A késői felső paleolitikum kutatástörténetében végig nyomon követhető a névadó lelőhely régészeti anyagának elkülönülése a többi lelőhely anyagától. A Lascaux/Ságvár interstadiális azonosításával kezdődött, majd a Ságvár periódus rétegtani-időrendi meghatározásával és néhány új lelőhely feltárásával folytatódott és (egyelőre) a ságvári kultúra körvonalazásával végződött ez a kutatástörténeti fejezet.

Kialakulásának ideje, helye, utóélete, földrajzi határai még ismeretlenek. A Kárpát-medence belső területein életrevaló, erőteljes, népes kultúrának mutatkozik. Nagy kiterjedésű, hazai viszonylatban gazdag telepeit ismerjük. Legalább két települési szintjének időrendi helyzete a ságvári geokronológiai periódus két határértéke: a két, embrionális talajképződést előidéző rövid interstadiális: a Laugerie és 
a Lascaux/Ságvár (Ságvár alsó és felső kultúrréteg, MadarasTéglavető, Szob: Markó 2007)

Majd néhány száz esztendős hiátus és néhány deciméter lösz lerakódása után a jégkor legvégéről is ismerünk egy gyenge leletes szintet, ami feltehetően az epigravetti utolsó települési hulláma (pl. Pilismarót-Bánom: Dobosi 2006).

Erre az egyelőre jelzésszerű szintre alkalmazhatnánk a Late Upper Paleolithic kategórián belül a terminal megkülönböztető jelzőt. A late és a terminal jelző alkalmazása a szakirodalomban általában fakultatív, ám ebben az esetben indokolatlan a már meghonosodott elnevezés megváltoztatása. A levantei felső paleolitikum újabb tagolásában LTUP jelöléssel önálló kulturális egységként szerepel. Időrendi kerete az európai terminológia szerinti teljes késői felső paleolitikum (LUP) (Minoru et al. 2011:104). Így egy új terminológiával (LTUP) és a korábban bevezetett Initial, IUP kategóriával a kissé leegyszerüsített, és ezért könnyen kezelhető, klasszikus hármas tagolás (EUP, MUP, LUP) immár ötösre bővült.

Dolgozatunkban az általános funkciójú és ásatással hitelesített, gravetti telepek topográfiáját vizsgáljuk (2.ábra). A topográfia első jelentésében helyleírást, tájleírást jelent. Speciális, régészeti értelmezésben pedig „szisztematikus lelóhely azonosítás, lelőhelykataszter” (MRT), valamint ,jelenségek (lelöhelyek) közötti (térbeli) kapcsolatok" (Reményi-Stibrányi 2011:190), aminek elemzésére kellő számú, azonos korszakból származó őskőkori lelőhely adatainak ismeretében idővel sor kerülhet. Jelen esetben egy adott nyílt színi lelőhely (egy paleolitikus kultúra lelőhelyeinek) szúkebb környezetével való kapcsolatát, a kedvező természetföldrajzi adottságok felismeréséből következő helykiválasztást értjük alatta.

A barlangok esetében a választás lehetősége jóval szúkebb. Barlangokban gazdag vidékeken azonban mód van a völgytalp feletti magasság, a lakótér mérete, a megközelíthetőség, a tájolás alapján válogatni. Nem lenne érdektelen a hazai barlangi lelőhelyeket ezen szempontok alapján elemezni időszakonként, kultúránként, funkciónként (ideiglenes vagy tartós lakótér, prémraktár stb.).

A műhelyek, Püspökhatvan és Arka a nyersanyagforrásokra települtek. A múhelyek között megkülönböztetendő az általános funkciójú telepeken belül elkülöníthető, a néhány négyzetdeciméterestől az 1-2 négyzetméteresig terjedő nagyságú mühelyfolt, ahol a technológiai hulladék alapján eszközöket készítettek vagy javítottak, és a nagy kiterjedésû nyersanyag-kitermelő helyeken szállításra vagy további felhasználásra végzett előkészítő munka helyszíne a múhelytelep. Ez utóbbi esetben tisztázásra vár, hogy ezekhez a helyekhez kapcsolódik-e hagyományos telep (ahogyan Vértes L. Arkán feltételezte - Vértes 1964-1965), szerencsés esetben hagyományos kultúrréteggel, vagy csak ipari tevékenység folyt.

A felső paleolitikum és az azóta eltelt időszak rövid a földfelszín nagy szerkezeti elemeinek geológiai léptékű változásaihoz képest, ám a jégkor végi és holocén kori folyamatos alakulás (lepusztulás, fel- és áthalmozás stb), majd az ember általi alakítás megnehezíti a telepek szúkebb környezetének rekonstruálását. A települési felszín, a kultúrréteg még a rövid ideig lakott átmeneti vadásztanyák esetében is, megmaradt in situ: megtelepedésre közel vízszintes, lapos

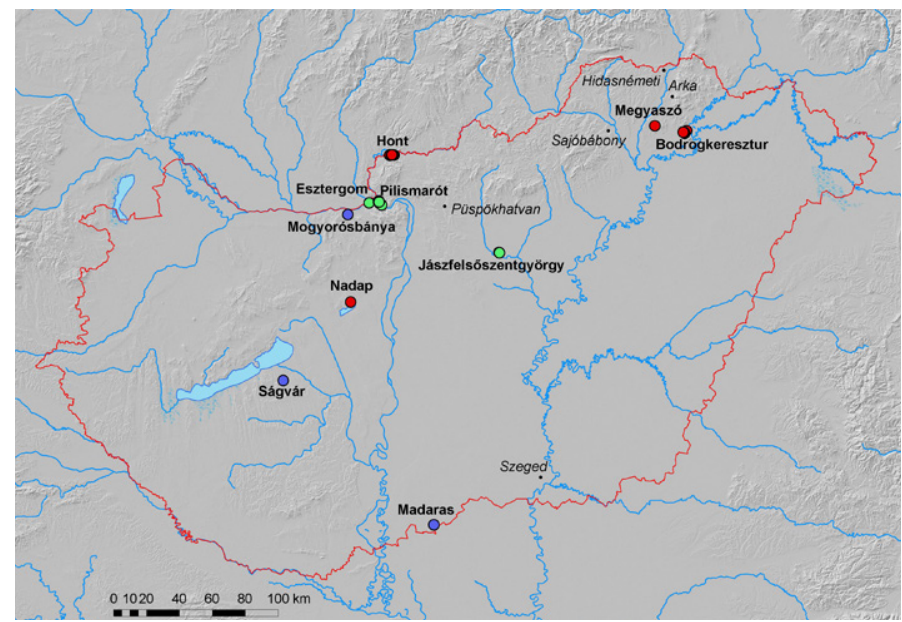

2. ábra. A szövegben említett lelőhelyek. Piros: pavlovi kultúra, kék: ságvári kultúra, zöld: epigravetti kultúra. //

Figure 2. Sites mentioned in the text. Red: Pavlovian culture, blue: Ságvárian culture, green: Epigravettian culture.

dombtetőket választottak. Csak a talaj víztartalmának térfogatváltozása (fagyása-olvadása) által okozott, ismert mechanizmus, később pedig a talajmúvelés bolygatta meg a felszín közeli telepeket. Az ismert periglaciális talajjelenségek (szoliflukció, fagyék) zavaró hatását hazai lelőhelyeken eddig nem tapasztaltuk.

A nyílt színi gravetti lelőhelyek felkutatásánál segítséget jelent a felismerés, hogy a kiválasztásánál nagy szerepet játszott a helyszín jelenleg még pontosan nem értelmezhető, ám nyilvánvaló természetföldrajzi-ökológiai potenciálja. Annak a bizonyos helyeken érzékelhető helyzeti előnynek a felismerése, ami egy vagy több felső paleolitikus kultúra lelőhelyeinek koncentrálódását vagy a többrétegú telepek létrejöttét eredményezi. Ilyen helyek pl. Wachau (Alsó-Ausztria) és a Pavlovi-hegy (Morvaország) tágabb környéke, mint a gravettiek közép-európai központjai, vagy a Vág völgye Moravany-nál, vagy a keletről nyugat felé tartó népmozgásoknak a Kárpátok keleti előterében feltorlódott, megállapodott csoportjai (a Prut és a Dnyeszter völgye), vagy akár a Don-kanyar (Kostienki és köre). Magyarországon ilyen a Duna-kanyar és az Ipoly-kanyar.

\section{Topográfia}

\subsection{Pavlovi kultúra}

Kiemelkedő hazai példa a lelőhelybokorra Bodrogkeresztúr környéke (3. ábra). A Zempléni-hegység déli vége és a Bodrogköz között minden dombon, a Kopasz-hegy lábán körbe gyűjtőpontok vannak. A terület különböző ökológiai fülkék előnyeit kínálja néhány négyzetkilométeren:

- délnyugatra a Takta-köz, a mocsaras biotóp gazdag és változatos vízi és szárazföldi faunával, amelynek vezérfaja az Alces;

- azon túl az alföldi száraz, füves sztyepp, innen került a telepre a mamut és a vadló;

- a folyók (Tisza, Bodrog) máig híresen gazdag halfaunája nem maradhatott kiaknázatlanul, bár a többnyire 

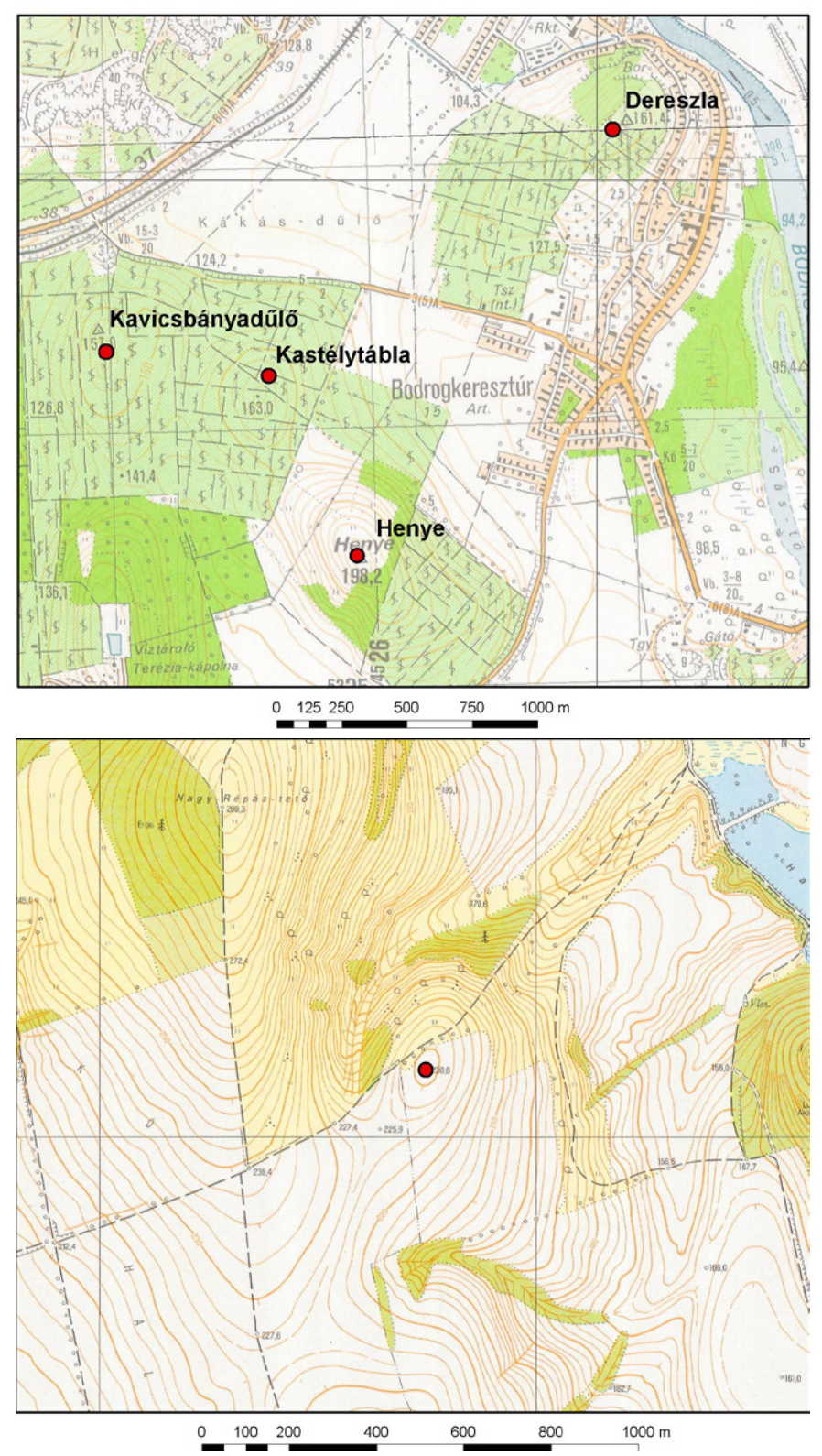

3. ábra (fent). Bodrogkeresztúr környéki lelőhelyek. 4. ábra (lent). Megyaszó-Szeles-tető. // Figure 3 (top). Bodrogkeresztúr and environs. Figure 4 (bottom). Megyaszó-Szeles-tető.

bolygatott kultúrrétegben nem találtuk nyomát;

- a folyók menti galériaerdőkből begyüjthették a szükséges faanyagot;

- északról, a zsákmányszerzés szempontjából legkevésbé kihasznált középhegység a változatos nyersanyagok gazdag forrása.

A terület az egész Kárpát-medencét obszidiánnal ellátó egyik központ. Még nem dönthető el, hogy az egész felső paleolitikum folyamán ismert és használt gyújtőhely a területileg éppen „illetékes” közösség fennhatósága alá tartozott-e, vagy „közkincs” volt?

A szőlő ültetvényekkel borított területen eddig a parlagon hagyott, ám többször mélyen felszántott Henye-tetôn és Tarcal-Citrom-bánya fedő löszében előkerült epigravetti telepen volt ásatás.
Bodrogkeresztúr-Henye egyike a kevés hazai mamutvadász telepeknek. Nagy kár, hogy csak részletei maradtak bolygatatlanul. A régészeti anyaga tipológiailag változatos, kivitelezésében magas színvonalú. Radiokarbon kora $28700 \pm 3000$ BP és $26318 \pm 365$ BP (Dobosi 2000).

Megyaszó-Szeles-tető akár Bodrogkeresztúr ikertelepülése is lehetne a hegy túloldalán a Zemplén délnyugati lábánál (Dobosi-Simán 1996) (4. ábra). Radiokarbon kora $27070 \pm 680$ BP. A Szerencsi-dombság kistáj Alföld felől számított második vonulatának 230 méter magas dombja, Ingvár és Nagyrépás között. A három oldalát határoló lejtő a pleisztocénben a kisebb erózió miatt kevésbé lehetett meredek. Körötte a magasabb dombok némi védelmet nyújtanak az időjárási szélsőségektôl. Ideális helyszín, illeszkedik a gravetti települési stratégiába. Mindaz érvényes, ami Bodrogkeresztúrra, kiegészítve a könnyen hozzáférhető Hernád-völgyi hidrotermális nyersanyagforrásokkal.

Hont-Parassa III./Orgonás is a leghagyományosabb topográfiai pozícióban van (Dobosi-Simán 2003) (5. ábra). Radiokarbon kora $27350 \pm 610$ BP. A Nagy-hegy északi lábán, az Ipoly középső teraszának meredeken leszakadó peremén tártuk fel Parassa III./Orgonás lelőhely egy részét. Közelebbről, pár száz méterre a határátkelőtől délre, a 2. sz. múútról a teraszra felvezető földút kanyarjában.

A községtől északra az Ipoly délkelet-északnyugati irányba fordul, a csaknem $5 \mathrm{~km}$ széles völgyét jól fejlett teraszrendszer kíséri, amely szervesen kapcsolódik a Börzsöny északkeleti hegylábi lejtôihez. A teraszokat egy-két száz méterenként az Ipolyba tartó patakvölgyek vagy száraz aszó völgyek tagolják. Hont környéke egyike a legjelentősebb lelőhely-koncentrációknak Magyarországon (Zandler 2011).

A teraszrendszer idősebb lépcsőinek kavicstakarója helyenként a tetőkön vagy mélyutakban kiékelődik, ami egyúttal hozzáférhető nyersanyagforrás is.

5. ábra. Hont környéki lelőhelyek. // Figure 5. Sites around Hont.

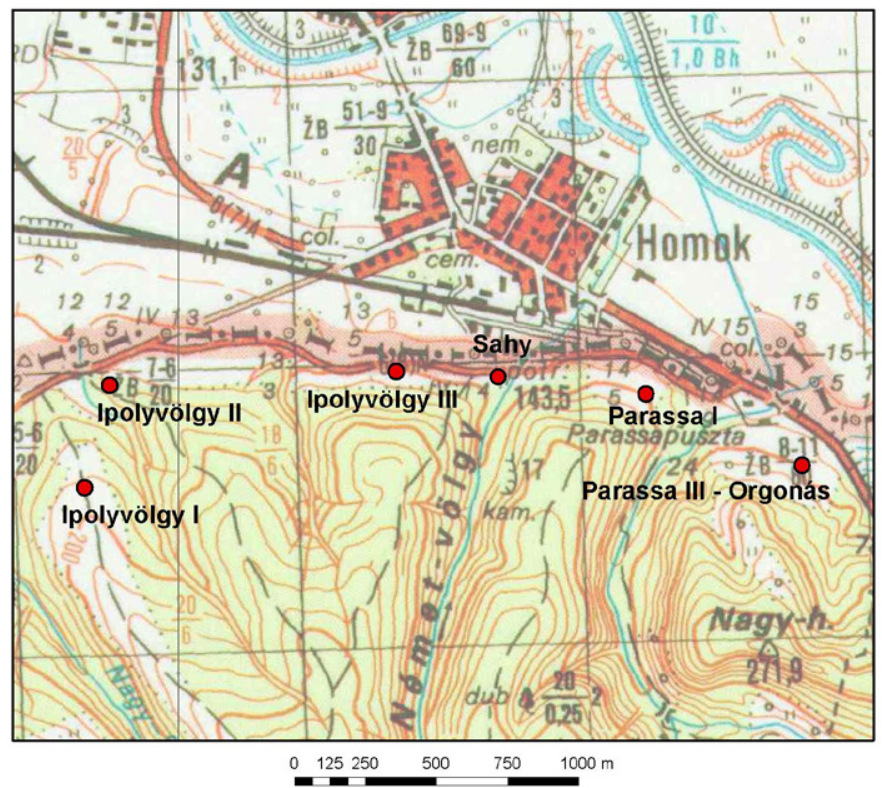


A fiatalabb, az allúvium fölé váltakozó magasságban emelkedő, különböző korú szinteken a felső paleolitikus telepek és mühelyek a faluban és a megye nyugati határáig terjedő szakaszon egymástól néhány száz méterre sorakoznak. Legalább három kulturális fílumba tartoznak.

A legfiatalabb lépcsőket a jelenkori ipari tevékenység (a bal parton múút, vasút, üzemek, a jobb parton Ipolyság települése) többnyire átalakította, elsimította.

Nadapon, a Velencei-hegység gránittömbjének keleti lábánál, egy aktív patakvölgybe torkolló mellékvölgy peremén, a felhagyott bazaltbánya elöterében került elö egy telep részlete (6. ábra). Az egymásba csatlakozó völgyrendszer kiválasztása hasonló a Hidasnémetiben tapasztaltakhoz (Simán 1989).

Északnyugatról védett (bányászással megbontott hegy tömbje), a többi irányban tágas perspektíva, jó kilátással a Velencei-tó lapályára. A homok/lösz kitermelés következtében épphogy a hitelesítésre maradt pár bolygatatlan négyzetméter A helyszín ma hozzáférhetetlen. Néhány éve, legutóbbi látogatásunkkor, mint a legtöbb felhagyott bánya, kommunális szemétlerakó volt. A telep nyersanyag használata miatt érdemel különös figyelmet. A kis eszközkészlet közel fele-fele arányban kiváló minőségű bar-na radiolaritból és fehér patinás (erratikus?) tűzkőből készült. A Velencei-hegységből ismert, gyenge minőségű kvarcitot nem használták.

A LUP két kulturális fílumának (a fiatalabb pengésnek, illetve a ságvárinak) a népessége eltérő települési stratégiát választott.

\subsection{Epigravetti kultúra}

A Duna jobb parti teraszrendszerének az Által-ér torkolatától (Tatai-árok) Budapestig tartó, bő 80 km-es szakasza alaposan kutatott. Geomorfológiailag Pécsi Márton és csapata kutatásainak egyik bázisa volt, Pilismarót-Basa-harc több

6. ábra. Nadap-Kőbánya. // Figure 6. Nadap-Kőbánya.

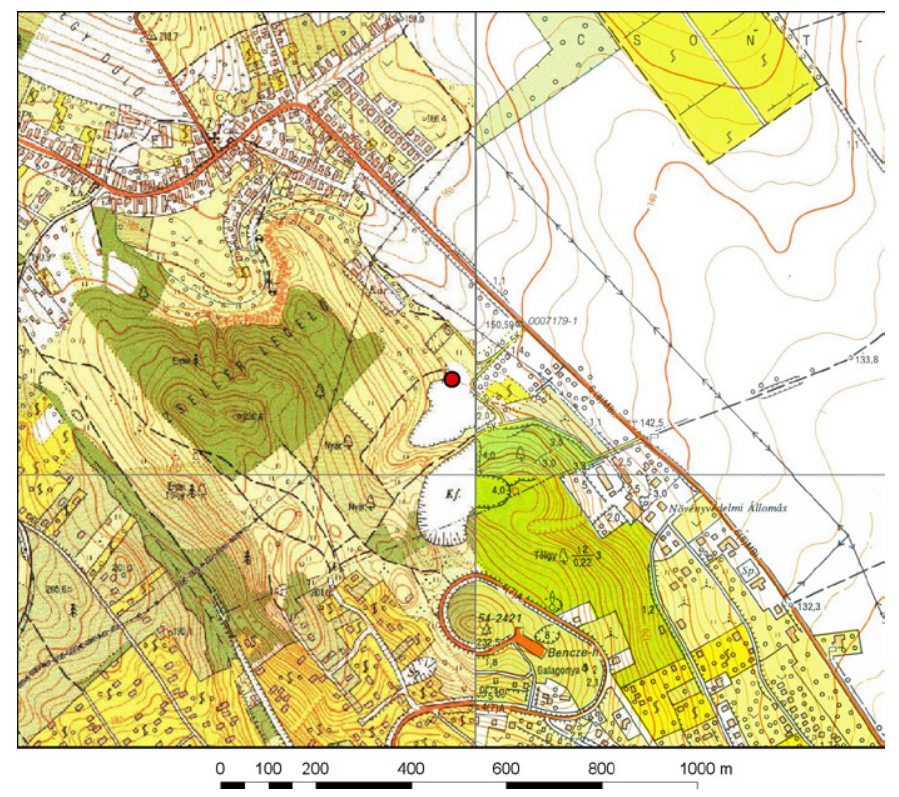

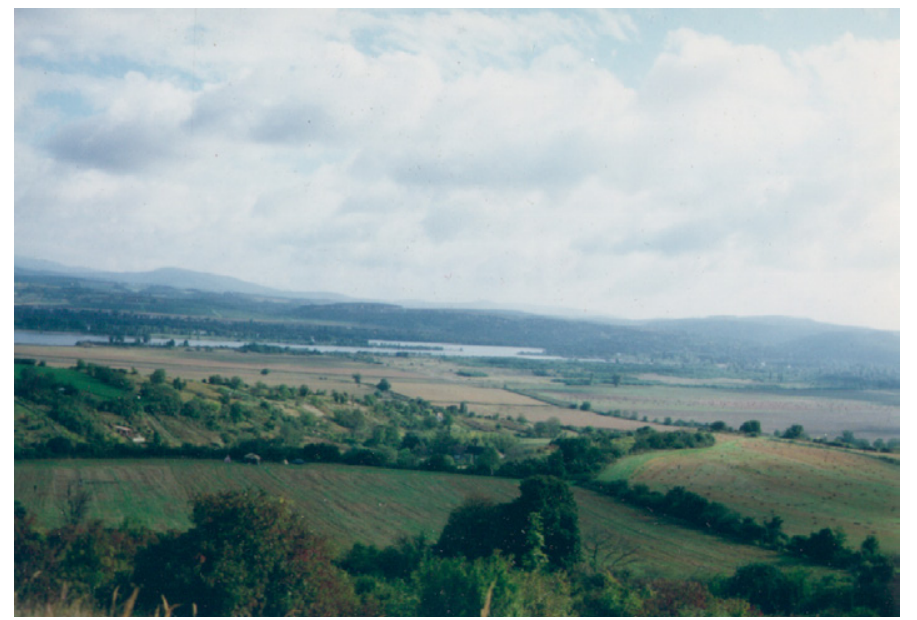

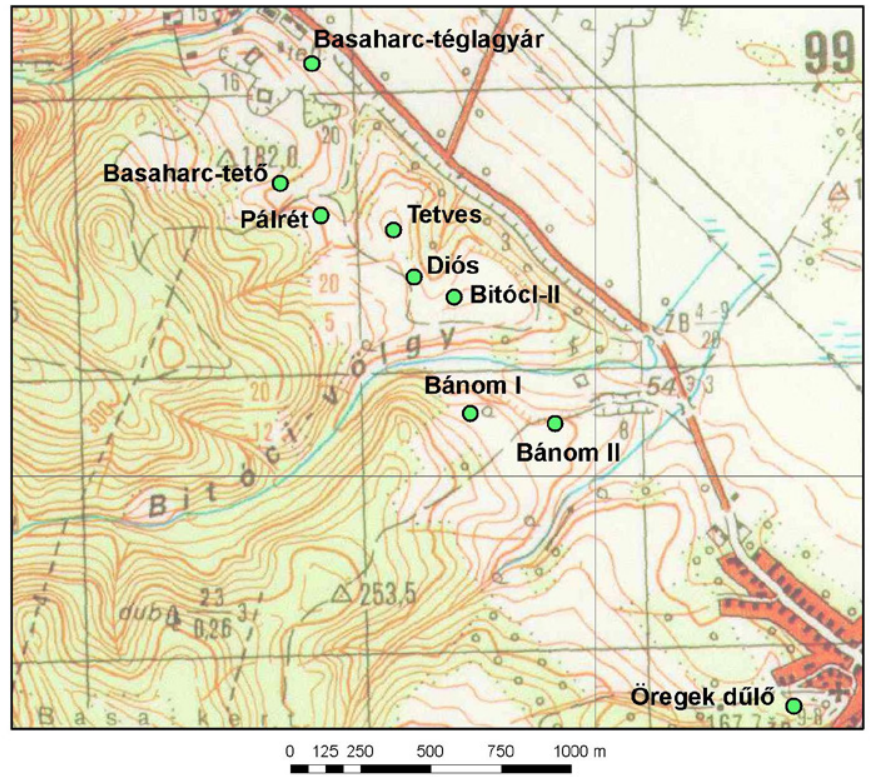

7. ábra (fent). Duna-teraszok Pilismarótnál. 8. ábra (lent). Pilismarót környéki lelőhelyek. // Figure 7 (top). Danube terraces at Pilismarót. Figure 8 (bottom). Sites around Pilismarót.

löszsztratigráfiai egység névadó lelőhelye. A régészeti feltárások a múlt század harmincas éveitől kezdődően, a néhai vízlépcső megelőző ásatásain és a topográfiai kutatások évein át csaknem valamennyi régészeti korszakban szép eredményekkel zárultak (7. ábra).

A dorogi öblözet kivételével (ott ugyanis a legszélesebb az allúvium, s a teraszok eltávolodnak a folyótól) Dunaalmástól Budapest-Corvin térig egymást követik az őskőkori lelőhelyek (Gábori 1964; Gáboriné Csánk 1984; Dobosi et al. 1983; 1991; Dobosi 2006; Ringer, Lengyel 2008-2009). Dömöstől Basaharcig a 11-es számú főutat kísérő teraszok pedig az epigravetti kultúra telepeinek hazánkban eddig példa nélküli koncentrációját képviselik.

Dömös előtt a szélesen elterülő Duna száraz időszakokban szigeteket, zátonyokat épít, s bizonyosan így volt ez a késő pleisztocénben is. Ideális őszi-tavaszi átkelőhely a rén csordáknak a mérsékeltebb éghajlatú középhegység és a Dunától északra elterülő lapály, a Kisalföld között. Ideális vadászati lehetőség. A Pilismarót-Pálrét lelőhely rén maradványai között talált tejfogak és állandó fogak csírái az 

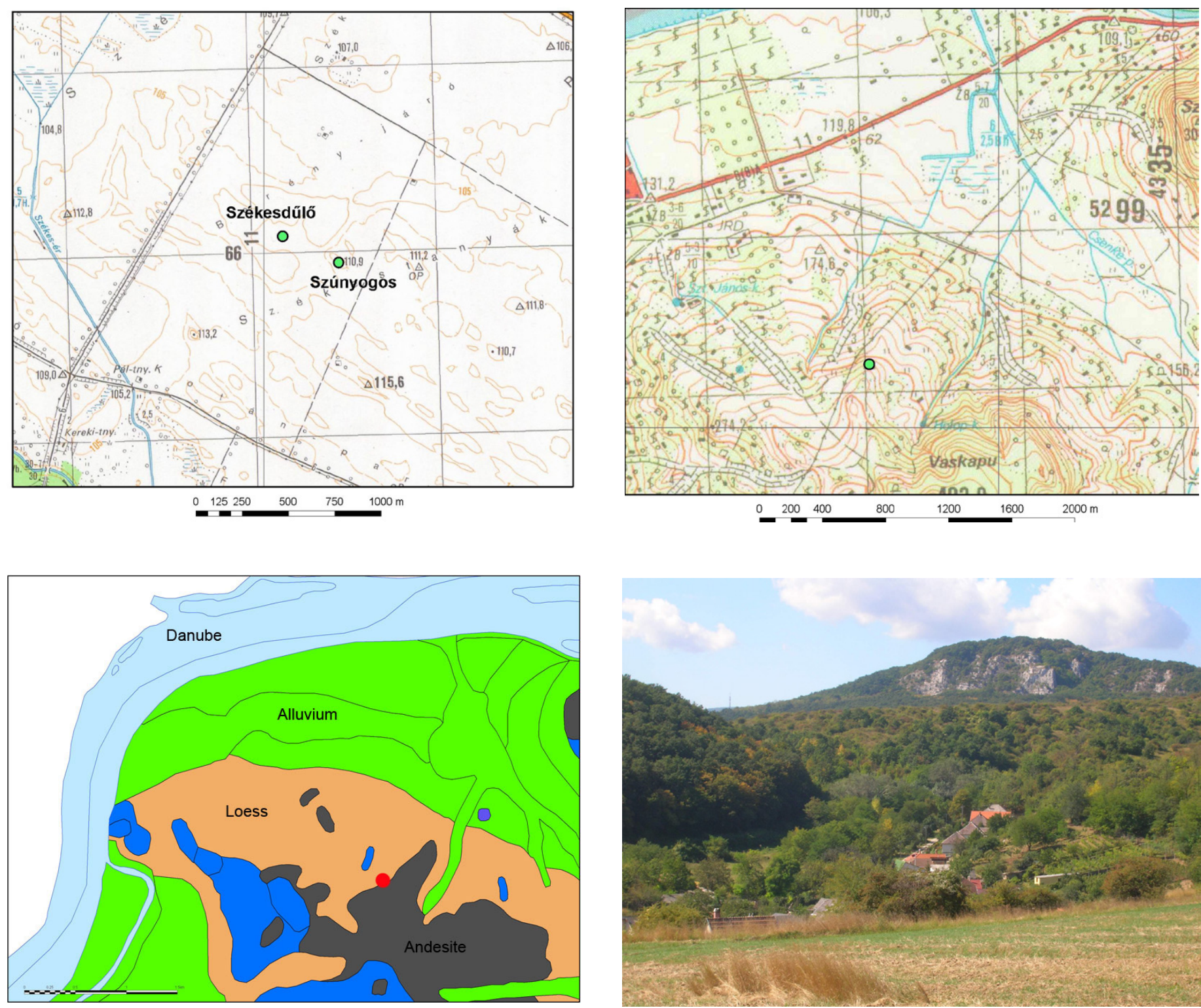

9. ábra (balra fent). Jászfelsőszentgyörgy Szúnyogos és Székesdűlő. 10 ábra (jobbra fent). Esztergom-Gyurgyalag. 11. ábra (balra lent). EsztergomGyurgyalag geológiai térképen. 12. ábra (jobbra lent). Mogyorósbánya, az Öreg-kő a lelőhelyről nézve. // Figure 9. (top left). Jászfelsőszentgyörgy Szúnyogos and Székesdűlő. Figure 10 (top right). Esztergom-Gyurgyalag. Figure 11 (bottom left). Geological map of Esztergom-Gyurgyalag. Figure 12 (bottom right). Mogyorósbánya, view of the Öreg-kő from the site.

őszi-téli vadászatot igazolják (Dobosi et al. 1983:299-304). A Kárpát-medencén belüli helyi jelentőségű, dél-északi vándorlás mellett az archeozoológusok egy jóval nagyobb léptékű nyugat-keleti rénvándorlást is valószínüsítenek a Duna völgyében a Dévényi-kapun keresztül („From High-Germany into Hungary”). Vörös I. (1982: 63) idézi A. D. Sturdy elméletét a csordakövető gazdálkodást (herds following economy) folytató közösségekről.

Pilismarót lelőhelyeinek sorozatából az Öregek-dűlő a legkorábban megismert nyílt színi lelőhelyeink egyike. A hét helyszínen végzett ásatások öt telepet eredményeztek (8. ábra). Pilismarót-Bitóc radiokarbon kora $17130 \pm 320$ BP, Pilismarót-Pálrété $13130 \pm 100$ BP. Basaharc-tető és DömösPattantyús hitelesítési kísérlete csak részben volt sikeres. A terepbejárások számos gyưjtőpontot azonosítottak. Basaharc téglagyári fejtőiből löszből vagy eltemetett talajból az epigravettinél idősebb leletek is előkerültek.
Az epigravetti időszak mozgékony vadászközösségei, hacsak egy-egy vadászatra is, de eljutottak az Alföldre. Az Észak-Alföldön a Zagyva és a Tarna völgye a legígéretesebb kutatási terület.

Eddig mindössze három (részben) feltárt epigravetti lelőhelyet ismerünk az Alföldön: Szeged-Öthalom, Jászfelsőszentgyörgy-Szúnyogos és -Székesdűlő (ez utóbbi két települési folt egy nagy kiterjedésü, komplex szerkezetû telephez is tartozhat). A szegedi lelőhely pontos helyének meghatározására tett kísérletünk a továbbbontott homokbányában eredménytelen maradt. A Jászságban Kerékgyártó Gy. terepbejárásai vezettek el a lelőhelyek felfedezéséhez. A kistáj felszíne egy, a Mátrától a Tisza völgyéig félkörívesen, lépcsőzetesen süllyedő térszín. A paleolitikus, mezolitikus és a kora neolitikus lelőhelyek részben ezekhez a geomorfológiai szintekhez kapcsolhatók. A Mátra lábához csatlakozó legfelső térszínt a felső paleolitikus, a középsőt a mezolitikus 


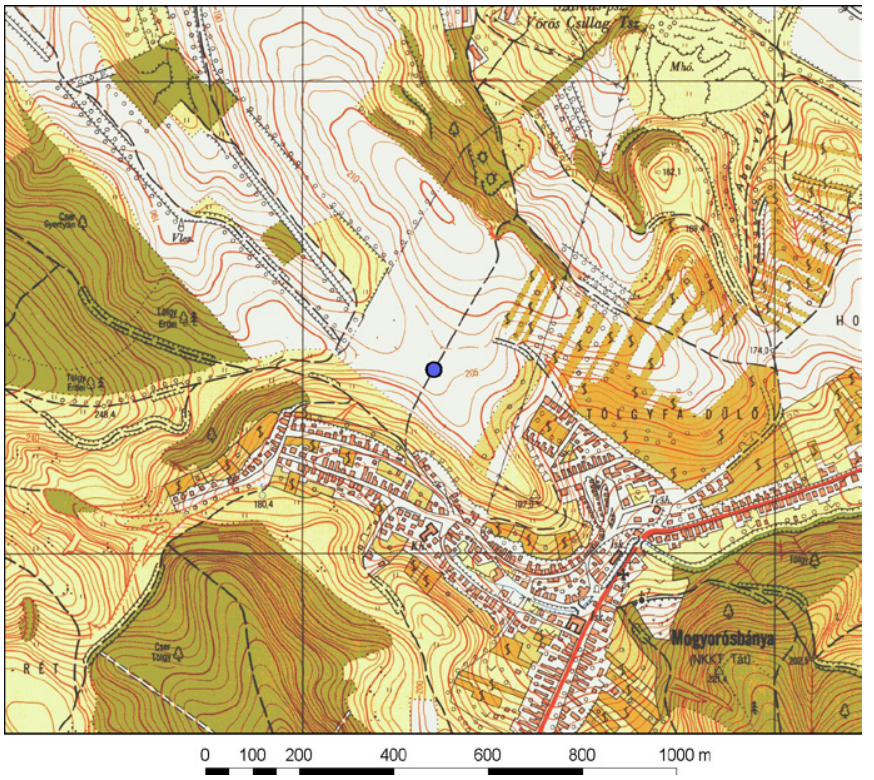

(Jászság), a 100 m tszf. alattit a kora neolitikus (Szolnok-Szanda, Szajol) időszakban vették birtokba.

A jászfelsőszentgyörgyi lelőhely a településtől mintegy 3 km-re északkeletre helyezkedik el (9. ábra). Ezen a területen a Zagyva jelenkori medrénél 8-10 m-rel magasabban garmadabuckák emelkednek. A 107-120 m tszf. magasságú, nagyjából északnyugat-délkeleti irányú jégkori maradványfelszíneket az ös-Zagyva lefüződött, feltöltődött meanderei veszik körül. Csapadékosabb időkben a süllyedékekben az évtizedes mezőgazdasági művelés ellenére most is megjelennek a vízinövények.

A falutól keletre, a Szúnyogos határrészben, 1 km-es körzetben több, néhány darabos felszíni gyưjtőpontot talált a Jászság terepkutatója, Kerékgyártó Gyula. Ebből, kettőt, egymástól kb. 200 méternyire. Szúnyogost, amelynek radiokarbon kora $18500 \pm 400$ BP (20 590-19 450 cal. BC), és Székes-dúlőt hitelesítettük. Tavasszal vadászhattak erre, mivel a kultúrrétegben madártojást (hófajd?) találtunk (Dobosi 2001).

Esztergom-Gyurgyalagon a leghagyományosabb hely-választás a legegyénibb, több szempontból is rendhagyó leletanyaggal párosul (10. ábra). Radiokarbon kora $16160 \pm 200$ BP (17 950-17 750 cal BC). Basaharctól tovább haladva a 11-es főút mentén Szamár-hegynél (a Hideglelös kereszt alatt) az összeszúkülő völgyben a Duna elmosta a teraszokat. A Sípoló-hegytől a városig ismét jól követhető a változó szélességü, patakvölgyekkel szabdalt Würm-kori teraszvonulat. Ez a város kiskertes üdülőövezete. A lelőhely a terasz peremén van, a Sípoló-hegy védelmében, arccal a Duna gázlóira és a bal parti lapályra (11. ábra).

\subsection{Ságvári kultúra}

Három lelőhely topográfiáját vizsgáljuk: a Duna mellett Mogyorósbánya, a Külső-Somogyi-dombság északi peremén Ságvár és a Telecskai-dombok északi peremén Madaras.
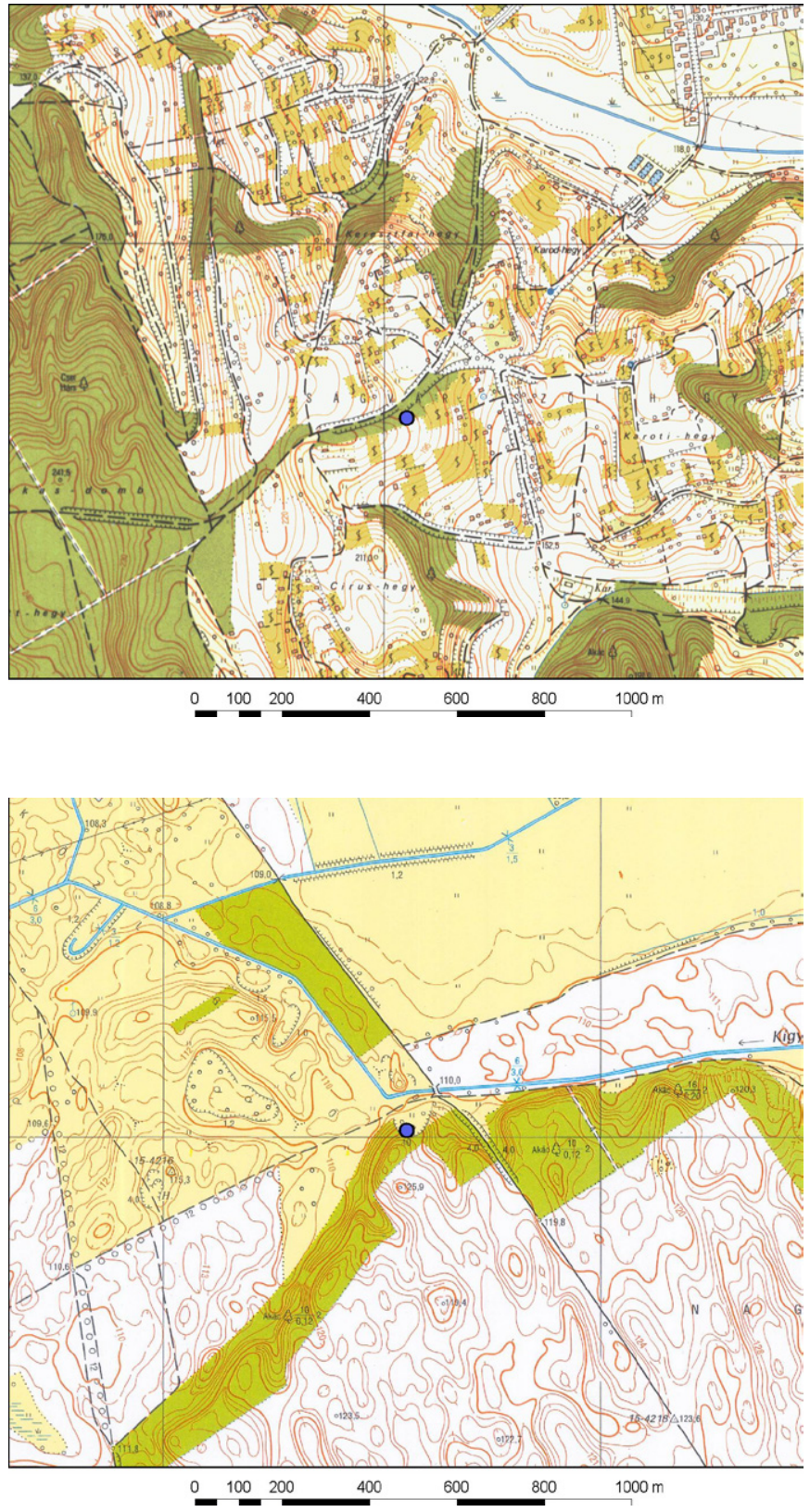

13. ábra (balra fent). Mogyorósbánya-Újfalusi dombok. 14. ábra (jobbra fent). Ságvár-Lyukas-domb. 15. ábra (jobbra lent). MadarasTéglavető. // Figure 13 (top left). Mogyorósbánya-Újfalusi dombok. Figure 14 (top right). Ságvár-Lyukas-domb. Figure 15 (bottom right). Madaras-Téglavető.

A Duna-kanyar felső őskőkori jelentőségére újabb bizonyíték, hogy az epigravetti mellett a ságvári kultúra két lelőhelye Mogyorósbánya és Szob is ebben a körzetben került elő. A jobb parton a dorogi öblözet után nyugat felé a Tatai-árokig a Gerecse hegylábi lejtőitől az alluviális síkságig folytatódnak a löszdombok.

Mogyorósbánya-Újfalusi dombok lelőhely a bajóti Öreg-kőtôl a Dunáig levezető patak völgye fölött, a lösz-domb sorozat 205-210 m magas belső tagjának peremén van, 204-206 m magasságban. Radiokarbon kora $19930 \pm 300$ BP és 19000 \pm 250 BP (21 050-20 300 cal BC) (12. ábra). A terasz völgy felőli peremének eredeti állapota nem rekonstruálható, mert építési törmelékkel feltöltött mesterséges lejtő. A Duna allúviuma felé meredeken leszakadó peremét növényzet védi az 

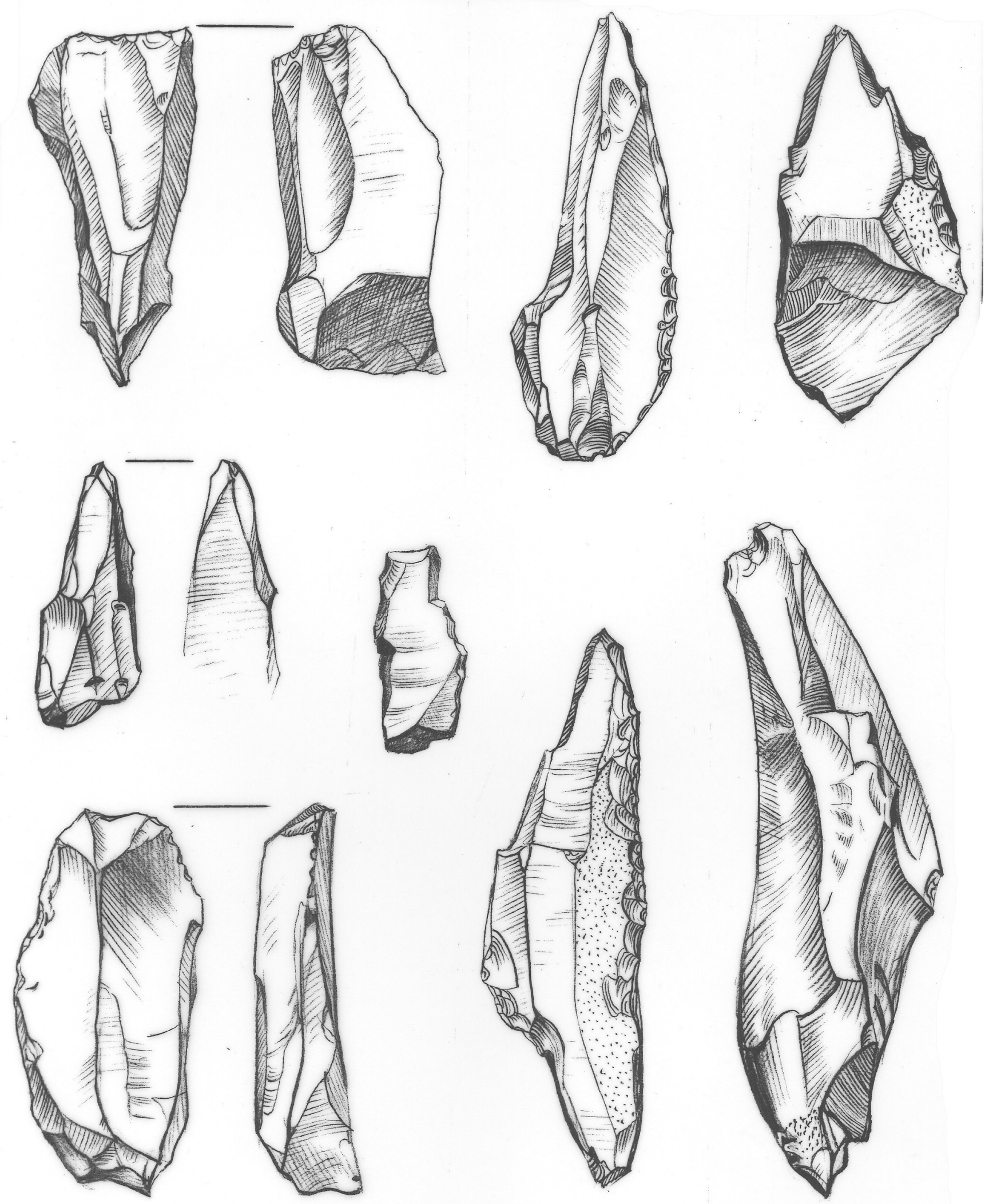

16. ábra. Pavlovi eszközök (Bodrogkeresztúr). // Figure 16. Pavlovian tools (Bodrogkeresztúr). 

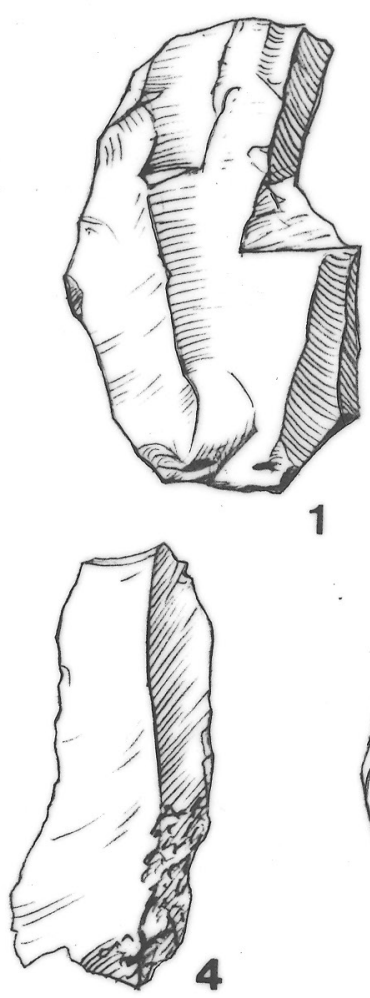

1

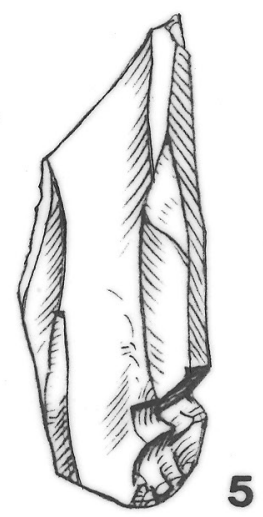

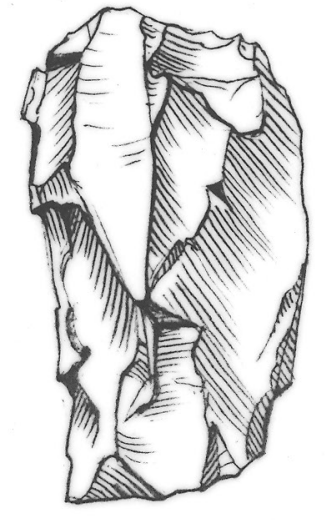

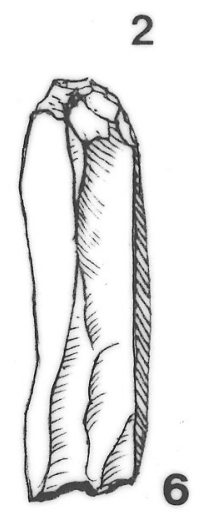

6

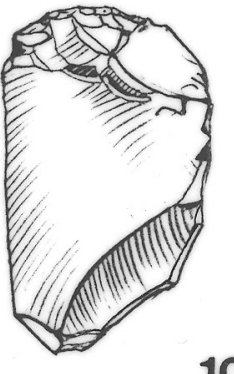

10

9

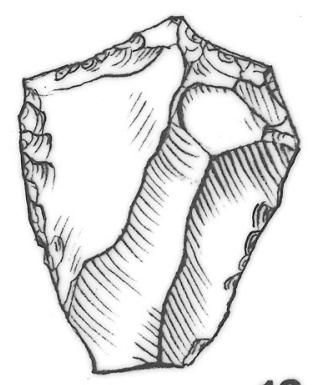

13

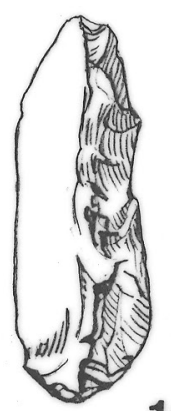

14

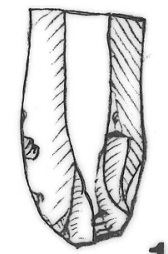

15
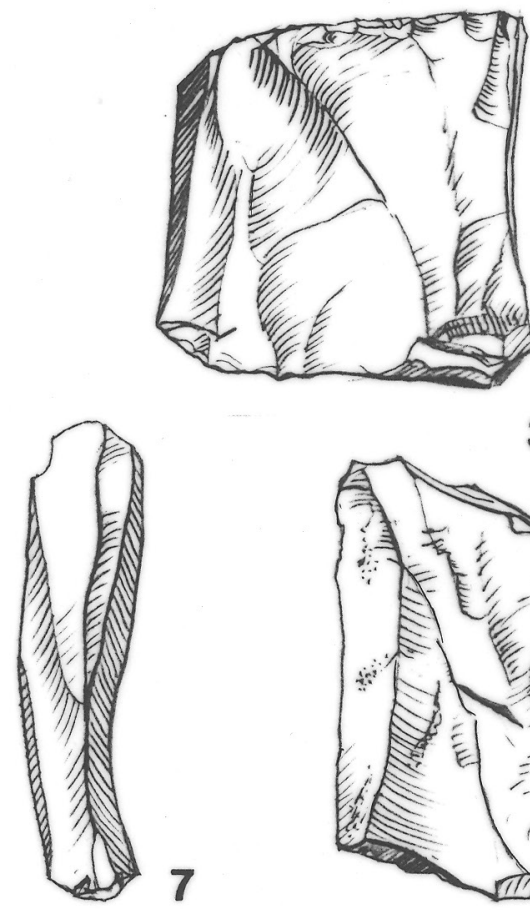

3
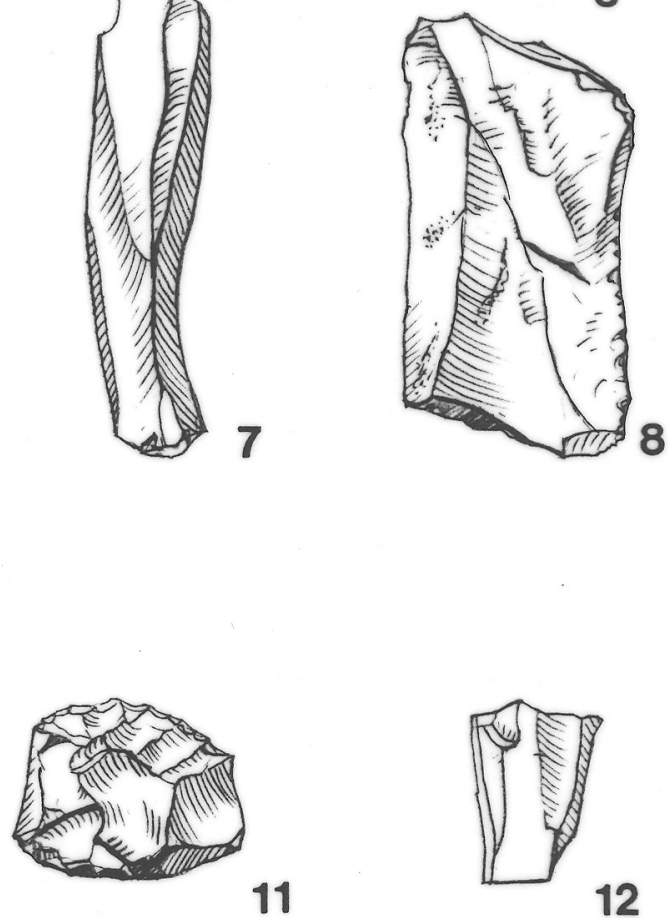

12

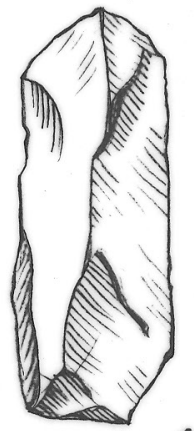

16

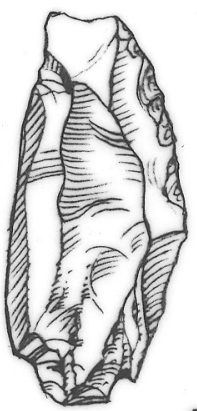

17

17. ábra. Epigravetti eszközök (Pilismarót). // Figure 17. Epigravettian tools (Pilismarót). 

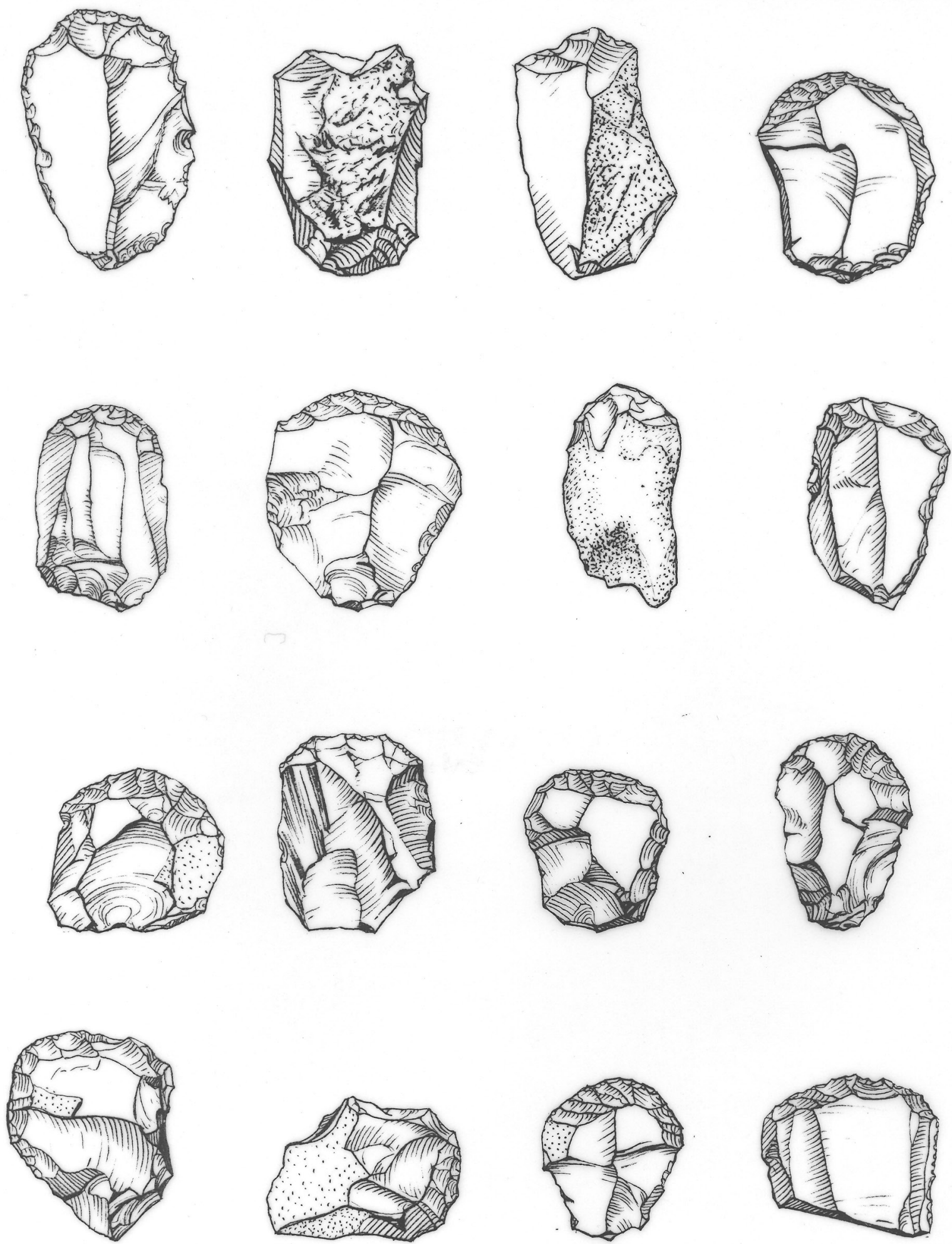

18. ábra. Ságvári eszközök (Ságvár). // Figure 18. Ságvárian tools (Ságvár). 


\begin{tabular}{|c|c|c|c|c|c|c|c|c|}
\hline & $\begin{array}{l}\text { Bodrog- } \\
\text { keresztúr }\end{array}$ & Hont & Megyaszó & $\begin{array}{r}\text { Pilismarót- } \\
\text { Bitóc }\end{array}$ & $\begin{array}{l}\text { Jászfelső- } \\
\text { szentgyörgy** }\end{array}$ & Esztergom & $\begin{array}{r}\text { Mogyorós- } \\
\text { bánya }\end{array}$ & Ságvár \\
\hline összes (db) / total (pcs) & 3589 & 1399 & 8263 & 1094 & 2003 & 1099 & 5040 & \\
\hline eszköz / tools (\%) & 22,0 & 9,3 & 6,8 & 12,0 & 6,2 & 37,0 & 8,9 & (431 db) \\
\hline vakaró / end-scrapers (\%) & 32,0 & 20,0 & 24,3 & 17,0 & 17,0 & 0,5 & 22,0 & 43,0 \\
\hline árvéső / burins (\%) & 33,0 & 38,0 & 21,1 & 32,0 & 20,0 & 25,4 & 40,0 & 24,0 \\
\hline hegy / points (\%) & 9,8 & 4,0 & + & + & + & 7,4 & 1,7 & \\
\hline tompított / backed (\%) & 6,6 & 8,4 & 9,1 & & + & 51,7 & 3,0 & 12,0 \\
\hline kaparó / side-scrapers (\%) & 4,6 & 6,0 & 7.8 & 7,0 & + & 2,1 & 5,3 & 4,0 \\
\hline magkő / cores (\%) & 4,5 & 3,5 & 5,5 & 3,0 & 3,0 & + & 4,0 & + \\
\hline penge / blades (\%) & 27,0 & 13,8 & 5,0 & 13,0 & + & 5,0 & 6,0 & + \\
\hline kavics / pebbles (\%) & + & 1,5 & + & 4,0 & & + & 18,0 & + \\
\hline
\end{tabular}

* Jászfelsőszentgyörgy-Szúnyogos és -Székes-dűlő eszközkészlete együtt érte el a százalékszámításhoz szükséges minimumot.

1. táblázat. Az eszköztípusok megoszlása lelőhelyek szerint. // Table 1. Distribution of lithic tool types at the sites.

\begin{tabular}{|c|c|c|c|c|c|c|c|c|}
\hline & $\begin{array}{l}\text { Bodrog- } \\
\text { keresztúr }\end{array}$ & Hont & Megyaszó & $\begin{array}{l}\text { Pilismarót- } \\
\text { Bitóc }\end{array}$ & $\begin{array}{c}\text { Jászfelsőszent- } \\
\text { györgy* }\end{array}$ & Esztergom & $\begin{array}{l}\text { Mogyorós- } \\
\text { bánya }\end{array}$ & $\begin{array}{l}\text { Ság- } \\
\text { vár }\end{array}$ \\
\hline hidro/limnokvarcit & + & $+(39)$ & $+(63)$ & & $+(>60)^{*}$ & $+(4)$ & $+(3)$ & + \\
\hline „kővelő" & + & & & & & & & \\
\hline obszidián & + & $+(2)$ & $+(27)$ & + & $+(5)$ & $+(0,1)$ & $+(5)$ & + \\
\hline radiolarit & + & $+(30)$ & $+(4)$ & + & $+(9)$ & & $+(6)$ & + \\
\hline tűzkő & & $+(2)$ & $+(3)$ & & $+(>3)^{\star \star}$ & & & $+* *$ \\
\hline erratikus tűzkő & + & & & + & + & & $+(6)$ & \\
\hline pruti kova & + & & & + & + & $+(94)$ & & $+* * *$ \\
\hline kova & + & $+(16)$ & $+(2)$ & + & $+* * *$ & & $+(73)$ & + \\
\hline szarukő & & & & & + & & + & \\
\hline szeletai kvarcporfír & + & & $+(0,5)$ & + & $+(2)$ & & & \\
\hline kvarcit & + & $+(7)$ & & + & + & $+(2)$ & $+(7)$ & + \\
\hline hegyikristály & + & + & + & $+* * * *$ & + & & + & \\
\hline egyéb & & $+(4)$ & + & & & & + & \\
\hline homokkő & & & & + & + & & & \\
\hline andezit & & & & & + & & & \\
\hline mészkő & & & & + & & & & + \\
\hline szerpentinit & + & & & + & & & & \\
\hline succinit & & & & + & & & + & \\
\hline
\end{tabular}

* Szúnyogos és Székes-dűlő összevonva. A nyersanyagok százalékos megoszlásában eltérések vannak a két feldolgozás között (Dobosi 2001; Priskin 2011).

** A tűzkövek zömmel távolsági nyersanyagok. Ságváron (Lengyel 2009:224) és Jászfelsőszentgyörgyön (Priskin 2011:35) Krakkó környéki jura tüzkövet azonosítottak.

*** Ságvárról Lengyel (2009: 224) volhíniai kovát említ, lehet pruti? Priskin (2011:35) Jászfelsőszentgyörgyön świeciechówi és csokoládé kovát azonosított

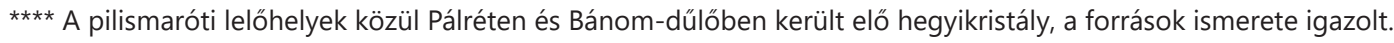

2. táblázat. A nyersanyagok megoszlása (illetve százalékaránya) lelőhelyek szerint. // Table 2. Raw material distribution (presence or percentage) at the sites.

eróziótól, a mezőgazdaságilag múvelt tetőn az erózió elmossa a humuszt, a felszín egyenetlenségeit folyamatosan elsimítja. A falu felőli domboldalon kiékelődött kultúrréteg vezetett a lelő-hely nyomára. Három, több méter széles leletmentes sávval elválasztott települési foltot tártunk fel. Az utolsó ásatási szezonban a III. települési folt pereme már a jelenlegi felszín alatt 180-200 cm mélységben volt. Ami azt jelenti, hogy az ôskőkori település idején a dombtető a tenger-szint felett 203-204 m magas és vízszintes volt (13. ábra).

A település helyének megválasztásában a lelőhelyek relatív, a környezetéhez mért magasságának van nagyobb jelentősége: ezek az adatok még nem állnak rendelkezés-re. További vizsgálódás tárgya lehet pl. a legközelebbi (jégkori) vízfolyással való kapcsolata is.

Ságvár, a kultúra névadó lelőhelye a Külső-Somogyidombvidéknek a Mezőföld felé nyitott északkeleti sarkában került elő, a Jaba-patak völgye fölött 228 m tszf. magasságú Lyukas-dombon. Az alsó kultúrréteg radiokarbon kora 18900 \pm 100 BP, míg a felsőé $17760 \pm 350$ BP (18 645-17 955 cal BC) (14. ábra). 
A mai pataknál jelentősebb vízfolyás egykori közelségét jelzi a ritka hód és a vidra jelenléte a faunában (Vörös 1982: 46). A helyszín - elsősorban a lösz szerkezetéből adódóan - erősen szabdalt, a tetőre felvezető horhos kettészeli a telepet. Számos kisebb-nagyobb ásatást végeztek a kulcslelőhelyen. A dokumentációkból az eredeti állapotok, a rétegsor rekonstruálása nem könnyú, s számolni lehet a leletanyag későbbi, már múzeumi keveredésével is. A települési jelenségek pontos rétegtani, abszolút és relatív időrendi helyzete éppen a ságvári kultúra körvonalazásához nyújtana fontos támpontokat:

- Valóban hármas tagolódású-e a Ságvár geokronológiai periódus (két interstadiális és közöttük egy ministadiális)?

- A két embrionális talajképződés egyidejü-e a nyugati klímaszakaszokkal, s ha nem, indokolt-e új, lokális terminus technicus bevezetése?

- A több alkalommal is regisztrált két kultúrréteg köthető-e ezekhez az interstadiálisokhoz?

A régi adatok újra értelmezése aligha lehet prekoncepcióktól mentes, így új, bolygatatlan telepek nagy felületekre kiterjedő, aprólékos feltárásától várhatunk új eredményeket.

Madaras-Téglavető a 108-110 m tszf. magasságú, víz-járta allúviumból 10-20 méterre kiemelkedő, egyenetlen felszínü löszfennsíkon helyezkedik el, amely a Szerbiából Magyarországra átnyúló Telecskai-dombok meredeken leszakadó peremével végződnek. Itt adja át a helyét az Illancs homokvidékének. Északi, promontor-szerû kiszögellését a szabályozott medrü, mára már jelentéktelen vízhozamú Kígyós-patak szegélyezi. Bár a Duna-Tisza-köze déli részének csatorna-hálózata alaposan átrajzolta az eredeti vízhálózatot, az orográfiai viszonyok alapján nem valószínú, hogy ezek a vízfolyások a jégkorszakban jelentősebbek lettek volna - ha léteztek egyáltalán. A domb peremét helyi téglaégetéshez szükséges „agyag” kitermelésére bontották meg. A mintegy 7 méter vastag lösz alatt váratlanul, de logikus helyen került elő az őskőkori telep (15. ábra). A lelőhely radiokarbon kora $18805 \pm 405$ BP.

\section{3. Összefoglalás}

A Kárpát-medence folyó- és patakvölgyekkel szabdalt löszvidéke, nagy csordaállat-eltartó adottsággal, az ökológiai fülkék mozaikos változatosságával, gazdag nyers-anyag választékkal ideális élettér a gravettiek számára az életmódjukból következően. A két időszak (MUP, LUP) telepeinek elrendeződésében azonban mutatkoznak különbségek, még ha a lelőhelyek csekély száma miatt ezek a tendenciák egyelőre nem is nevezhetők törvényszerüségnek.

A pavlovi vagy idősebb pengés települési hullám feltehetően a túlnépesedett(?) közép-európai gravetti központokból (Pavlov, Wachau) jutott el az ország északi sávjába. Két központi terület bontakozik ki: a Tokaj-Eperjesi hegység déli vége, és az Ipoly-könyök.

A települési stratégia egységesnek mondható, a települési formák, telepjelenségek valamennyi jelentős hazai lelőhelyünkön (Bodrogkeresztúr, Hont, Megyaszó, Sajószentpéter) hasonlóak: általános funkciójú telepek nagy perspektívájú stratégiai pontokon. Ezek a helyszínek lehettek állandó állatvonulási útvonalak, s a csordaállatokat követő vadászati módszerek következtében a nagyvadászatok ésszerű stációi. Ugyanakkor lehettek más szükségletek által meghatározott, rendszeresen járt útvonalak (pl. nyersanyagbeszerzés) megállói is.

A középhegységek teraszszerű hegylábi lejtőit, a hegyvidék és alföld közötti átmeneti zónát keresik. Az általában 230240 m tszf. magasságnál nem magasabb vízszintes tetőket a környező domboktól többé-kevésbé meredek lejtők szigetelik el, a dombsornak nem a legmagasabb és nem is a legszélső tagjai, tehát az időjárási szélsőségek ellen némileg védettek, déli kitettségűek. Néhány $\mathrm{km}^{2}$-en belül több, egymástól gyökeresen eltérő ökológiai fülke érintkezési pontja, változatos élelemforrással, élővíz közelében, többnyire a nagy folyók teraszait átvágó mellékpatakok védettebb völgyében, könnyen hozzáférhető, gazdag nyersanyagforrások közelében.

A horizontálisan nagy kiterjedésű, akár többszáz négyzetméteres telepeken a kultúrréteg kevésbé intenzív, mint azt a fiatalabb telepeken tapasztaljuk. Az egész dombtetőt beborító, szórt települési jelenségek észlelhetők egy vagy több szintben (Hont, Megyaszó). A települési felszín eszközök, szilánkok, konyhahulladék, hamufoltok, okker- és faszénszemcsék laza szövevénye. Az állatcsontok fosszilizációja esetleges, a bezáró üledék jellegétől függ.

Ez a települési szerkezet nagyobb közösség ismétlődő, de egy-egy alkalommal rövid ideig tartó megtelepedésére jellemző, és nem kis közösség tartós helyben lakására. A késői felső paleolitikum két kulturális fíluma (fiatalabb pengés, epigravetti illetve ságvári) népességének települési stratégiája némileg eltér a korábbi időszakokétól.

Az epigravetti kultúra telepei az egész ország területén megtalálhatók. Az Alföldön jégkori maradvány-felszíne-ken egy-egy szóló vadásztábor, a hagyományos folyó teraszokon egy-egy kis térségben sürüsödő lelőhelybokor (az Ipolyterasz Hontnál, a Duna-kanyar Dömös és Basa-harc között). Ezek a körzetek nagy folyók lösszel borított, száraz vagy aktív patakvölgyekkel szabdalt teraszlépcsői. A völgyek jelentik az összeköttetést az erdős hegyvidék (esetenként a barlangok!) és a gázlók, az alluviális síkság között embernek, állatnak egyaránt. Sürüsödnek a lelőhelyek az obszidiánvidéken (pl. Tarcal-Citrom-bánya a Nagy-Kopasz egyik kis nyugati „mellékhegyén”. A szlovákiai lelőhelyekkel a Hernád-völgy jelenthette a kapcsolatot, itt fontos szerepe lehet ArkaHerzsarétnek és a többi hitelesítésre váró gyưjtőpontnak. Az egyelőre szóló telepek, Budapest-Csillaghegy és a szakma nagy vesztesége, az elpusztult dunaföldvári lelőhely kóbor vadászközösségek elszigetelt szállásainak tûnnek.

A löszdombok után megszállják az állandóan vízjárta, mocsaras területekből kiemelkedő alföldi szárazulatokat. Az Alföldön eddig egymástól elszigetelve és nagy távolságra kétféle módon kerültek elő a lelőhelyek:

- A Jászságban a Zagyva allúviuma 100 m tszf. magasságú tereplépcső. Az eddig hitelesített két epigravetti telep homokos lösszel fedett hátakon, földfelszín közeli helyzetben van. 
- A jelenkori felszín alatt 4,5 méter mélyen került elő az epigravetti eddig egyetlen dél-alföldi lelőhelye, SzegedÖthalom. A Tisza allúviumából mintegy 90 m tszf. magasságával kiemelkedő domb megbontásakor két, egymástól jól elkülöníthető szintben kis felső paleolitikus vadásztanya maradványát tárták fel. Felbukkanásuk a löszdombok profiljában, anyagnyerő helyeken, bányagödrökben továbbra is várhatók, bár ennek egyre kevesebb az esélye a kisüzemi téglagyártás megszúnésével.

A nyersanyagforrásoktól és az ismert hazai epigravetti lelőhelyektől is távol, a helyválasztást két tényező indokolta. A Tisza árteréből kiemelkedő öt halom, valamint a keleti kapcsolatok egyik lehetséges útvonala, a Maros völgye, hiszen a pár darabos leletegyüttesben van pruti kova. SzegedÖthalom talán a kevéssé ismert észak-bácskai lelőhelyekhez kapcsolható.

Az epigravetti két kulturális horizontja közül az idősebbikbe sorolható lelőhelyek rövid élettartamú telepek. Bár a faunaösszetétel, a telepek topográfiája, a kultúrréteg csekély intenzitása, kiterjedése alapján ezek csaknem bizonyosan szezonális vadásztanyák voltak, a feldolgozás jelenlegi szintjén a régészeti leletanyagban ilyen irányú specializálódást nem tapasztaltunk.

A LUP legfiatalabb szakaszáról tudunk a legkevesebbet. Az epigravetti fiatalabb horizontjának leletei a lösz tetején, természettudományos kísérő anyag és települési jelenségek nélkül, bolygatott pozícióban kerülnek elő.

A Jászságban, Pilismarót-Bánom lelőhelyen közvetlenül a humusz alatt, de már a löszben figyelhető meg egy gyenge leletes szint. Önálló telepei azok a Würm végi lelőhelyek lehetnek, amelyek egy-két darabos szórványleleteit 11-12 ezer éves korú üledékben találták meg (Dunaföldvár, Zalaegerszeg). A lelőhelyeket nem volt mód hitelesíteni: elpusztultak, nem azonosíthatóak stb.

Pilismarót-Pálrét kronológiájában van némi ellent-mondás. A lelőhely földrajzilag és régészetileg is illeszkedik a DiósTetves-Bitóc-Bánom sorba, ám dátuma fiatalabb a vártnál: $13130 \pm 100$ BP (Hv-12988). A telepet több, mint 1 méter vastag, helyben keletkezett lösz fedi. Néhány száz méterre, Pilismarót-Bánom lelőhelyen megfigyeltünk egy jégkor végi települési szintet, közvetlenül a humusz alatt, amelynek becsült kora rétegtani helyzeténél fogva ugyancsak 12-13 ezer év. Miután a jégkor legvégének klimatikus viszonyaival, a holocént közvetlenül meg-előző mikrostadiálisaival nehezen egyeztethető össze egy méter vastag lösz lerakódása, és sem itt Bánomban a lapos teraszon, sem a Jászságban az azonos rétegtani helyzetû települési szintek esetében az egy méternyi üledéket lemosó erőteljes eróziót nem indokolja semmi. A két település aligha lehet egykorú. A pálréti dátum feltehetően nem pontos. M. A. Geyh az adatkísérő levelében a csigahéj vizsgálatának nehézségeiről azt írja, hogy az izotópok akár 20\%-a is kicserélődése a holocén folyamán).

A ságvári kultúra telepeiből még keveset ismerünk. A lelőhelyek topográfiai helyzetéből kiindulva kultúra-specifikus törvényszerúség nem fedhető fel a helykiválasztásban. Az az epigravetti fílumra jellemző helyen, Duna-teraszon, mély patakvölgy peremén is előkerült (Mogyorósbánya). Az alföldi löszdombok szélén is mindkét fílum megtelepedett: Madaras 7 méter mélyen a felszín alatt, Szeged-Öthalommal egyezően. A Balatontól délre, a jelentéktelen Jaba-patak egyike annak a kevés vízfolyásnak, amely a Somogyi-dombságra jellemző dél-északi irányú völgyekre csaknem merőlegesen keletre, a lapályra vezet. Mellette a dombtetőn Ságvár. Szob helye specifikus: ékszercsiga gyüjtésre rendezkedtek be.

Agravetti telepek szerkezete három típusra osztható. Miután egyetlen olyan felső paleolitikus lelőhelyünk sincs, amelyet teljesen feltárt telepnek nyilváníthatnánk, ez a csoportosítás bármikor módosulhat. Az első típus, a legkevésbé településszerü a szórt kultúrréteg. Pilismaróton az egy hektárnyi teraszszakaszon nyitott valamennyi kutatóárokban éppen csak a hajdani járószint azonosításához elégséges lelet volt. Ha a dombtető további feltárása során megtaláljuk a leletek néhány négyzetméteres koncentrálódását, akkor ez sátras települési forma. Pilismarót-Tetvesen a kettő kombinációja van, amely a második típust képviseli. A 15-20, esetenként valamivel több vagy kevesebb négyzetméteres, oválishoz közelítő kultúrréteg-foltok nem éles határral végződnek, hanem a leletek fokozatosan gyérülnek. Bár régészeti nyomát egyelőre csak Dömösről ismerjük (Gábori-Csánk 1984), mégis feltételezhetjük, hogy eredetileg volt valamilyen ideiglenes szárnyék, szélfogó vagy sátor a felszínen. A harmadik típus, a legfejlettebb a ságvári kultúrára jellemző. Az ismert telepeken tapasztalt jelenségek több kisebb, feltehetően családi egységekre bomló népes közösség intenzív ott-tartózkodásának jeleként értelmezhetők. Ezt nevezhetjük komplex településszerkezetnek. Ságváron két, félig földbe mélyített kunyhó, Mogyorósbányán három, egymástól leletmentes sávval elválasztott, több méter átmérőjü települési folt, Madarason több nagy méretű, gyưrüs szerkezetű tűzhely. Nyílt színi lelőhelyen az egyetlen kövekkel körberakott, tartós használatú tüzhelyet Szobról ismerjük (Markó 2007: fig. 1).

A topográfiai áttekintés után a gravetti entitás három kultúrája elkülönítésének jogosságát illusztráló néhány kép és adat következik.

A sokáig etalonnak számító Bordes-Sonneville-Bordes listákról hamar bebizonyosodott, hogy módosítások és megalkuvások nélkül nem alkalmazhatók a hazai leletanyagra. A típuscsoportok összevetése reálisabbnak tünik. Egyrészt, nem valószínü, hogy valamennyi formailag megkülönböztetett altípus különböző funkciót fed. Egy-egy altípus megkülönböztetése csak akkor jogosult, ha a darabszám lelőhelyenként eléri a statisztikai határértéket, illetve egy földrajzilag jól körülhatárolható lelőhelycsoportra jellemző újítás. Másrészt a típuscsoportoknak az eszközegyüttesen belüli aránya következtetni enged a környezetre is. Míg a bőr (és kisebb mértékben a csont) megmunkálása minden őskőkori kultúrában alapfeladat, addig a fa megmunkálására alkalmas típusok magas aránya fában gazdag (interstadiális?) környezetet feltételez.

A típuscsoportok összehasonlítása sem járt egyértelmû eredménnyel (1. táblázat). A pavlovi lelőhelyeken a vakarók és az árvésők aránya nagyjából egyforma (három lelőhelyből kettőben), és viszonylag magas a kaparók aránya.

Az epigravettiben az árvésők aránya nagyobb. Esztergom minden szempontból egyedi. A legszokatlanabb a normál mérettartományba tartozó, szabályos pengék tompításának kiugróan magas aránya. 


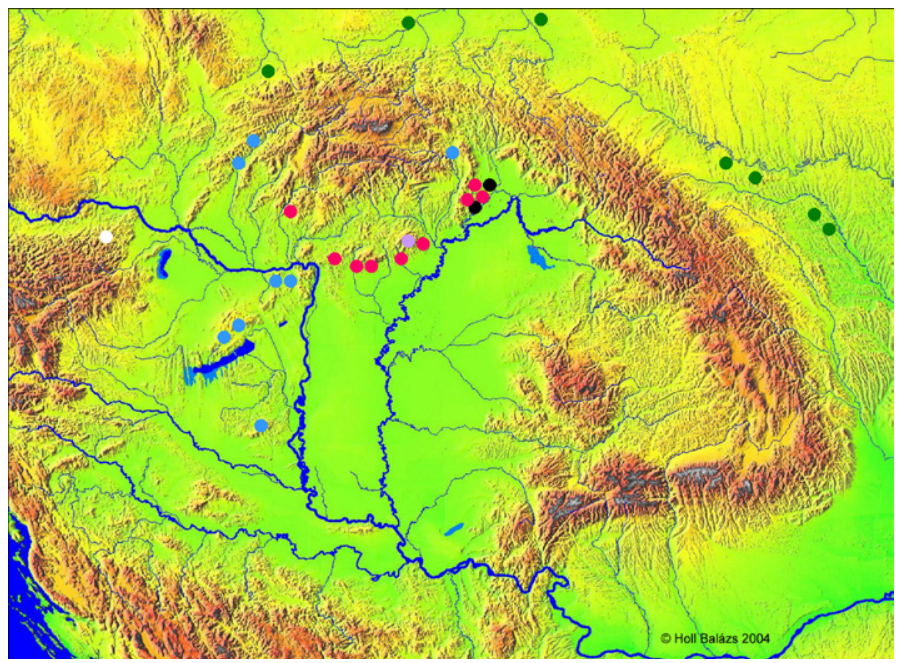

19. ábra. A felső paleolitikum ismert nyersanyagforrásai. Kék: jura kori radiolarit, zöld: kréta kori tűzkő, piros: posztvulkáni hidrotermális kovák, fekete: obszidián, lila: szeletai kvarcporfír. // Figure 19. Known raw materal sources during the Upper Palaeolithic. Blue: Jurassic radiolarite, green: Cretan flint, red: post-volcanic hydrothermal flints, black: obsidian, lila: Szeletan quartz-porphyry.

A ságvári kultúrát elsősorban a kavicsfelhasználás magas aránya, ebből következően a klasszikus pengék és pengeszármazékok hiánya különbözteti meg az epigravettitől. A felső paleolitikumot tárgyaló korábbi publikációkban a kavicsszekciót nem tekintették a leletanyag szerves részének, jobb esetben is csak megemlítették. Ebből következően a valós arányok csak további tételes revízióval mérhetők fel.

A gravetti entitás idősebb, pavlovi szakaszának jellemzői az eszközkészlet változatossága, a kivitelezés kiváló minősége, valamint az eszközöknek a fiatalabb gravettiekéinél szignifikánsan nagyobb méretei (16. ábra).

A két gravetti fílum közötti különbségek az eszköztípusok arányaiban, az eszközök kisebb méretében és a kevésbé szabványos kivitelezésükben mutatkoznak meg (17-18. ábra).

Annak ellenére, hogy már három évtizede hatékony terepi és múszeres nyersanyagkutatás folyik erős publikációs háttérrel, a régészeti közlemények egy része beéri a nyersanyagok puszta felsorolásával, s a megnevezések még mindig nem tekinthetők egységesnek. A téma fontossága különösen az egyéb információkban szegény paleolitikum kutatásában szakmai közhely, egy-egy közösség kapcsolatainak iránya, tevékenységi körének hatósugara, a regionális és távolsági nyersanyagok felhasználásával bizonyítható és mérhető (19. ábra).

A geológiai forrásokról, útvonalakról, a Kárpátokon átívelő vice versa kapcsolatokról rendezett konferencián (Krosno, Lengyelország, 2009) számos kutató foglalkozott a Kárpát-medencét közvetlenül is érintő témával. M. Lanczont és J. Wojtanowicz szerint a Tátra tömbje kivételével a Kárpátok megtelepedésre alkalmas hegyvidék. A nyugat-keleti kommunikáció, nyersanyagforgalom mindkét irányban múködött, a lapos hegylábi platók jól járhatók voltak (Lanczont-Wojtanowicz 2010:52). A Morva-kapunak fontos szerepe van a Szilézia és Morva-ország közötti kapcsolatrendszerben (és tovább a Duna völgye felé DV), amelyet a felső paleolitikumban elsősorban az erratikus nyersanyag közvetít. A Kárpátok és a Szudéták nem jelentettek akadályt a transzkárpáti migrációban (Bobak- PołtowiczBobak 2010:52).

Az őskőkorkutatás korai felismerése, hogy a Kárpátok és az időnként jéggel borított észak-európai síkság közötti folyosó emberek, kultúrák, állatok, innovációk, nyersanyagok áramlásának a legfontosabb közép-európai útvonala.

P. Valde-Nowak e minden szempontból régóta ismert útvonal mellett egy, észak-déli utat is feltételez (Valde-Nowak 2010:59-60). Ezeket az elméleteket igazolja, hogy a Kárpátmedence belsejébe több irányból érkezett be távolsági nyersanyag az őskőkor késői szakaszában. Az érintett geológiai források északon Krakkó környéke, a Szentkereszt-hegység, északnyugaton a sziléziai végmorénák, nyugaton az Alpok völgyei (hegyikristály), keleten a Prut völgye és Volhínia (?).

A fordított irányú mozgást bizonyítja a Kárpátokon kívüli területek felső paleolitikumában:

- az obszidián Lengyelországban a Visztula-medencében, Ausztriában a Wachau lelőhelyein (Dobosi 2011), Morvaországban a gravetti és a magdaléni telepeken (Valoch 1987:266; Oliva 1998: 48; 2002: obr. 6);

- a szeletai kvarcporfír a morvaországi levéleszközös (Valoch 1987; Oliva 2002: obr. 2) és aurignaci lelőhelyeken (Oliva 2002: obr. 3);

- magyarországi vagy szlovákiai, de mindenképpen a Kárpátokon belüli limnokvarcit Krakkó környékén (pl. Piekary IIA - Wilczynski 2006: 188);

- szentgáli szilicit (radiolarit) a morvaországi aurignaci és magdaléni lelőhelyeken (Oliva 2002: obr. 3, 6).

A nyersanyagbázis a vizsgált lelőhelyek alapján a gravetti időszakban azonos. A pattintott kőeszköz készítésére alkalmas, ma ismert elsődleges vagy másodlagos források zömét kiaknázták. Vannak azonban olyan nyersanyagnyerő helyek, amelyeket még nem azonosítottunk.

A nyersanyagfélék arányai változnak a geológiai forrástól való távolságtól függóen: az alföldi lelőhelyeknél - helyi nem lévén - a regionális és a távolsági, az észak-magyarországi lelőhelyeknél elsősorban a helyi nyersanyagok dominálnak stb. A helyi, regionális és távolsági jelzőt a litotéka-katalógus értelmezésében használom (Biró-Dobosi 1991: 8). Egyes lelőhelyeken belül az arányai is módosulhatnak, vagy új nyersanyagok is feltünhetnek a feltárás előrehaladtával.

Az újabb régészeti feldolgozásokban nem kap elég hangsúlyt az a régi felismerés, hogy egy-egy őskőkori kulturális egység meghatározásának fontos eleme a metrikus adatok által nyújtott objektív információ. Ezek az adatok legalább annyira jellemzőek egy iparra, mint az eszközelőállítás folyamata, amelynek vizsgálata viszont népszerú. Szemléletes, ha nem is felső paleolitikus példa erre az alsó és középső paleolitikum mikrolitikus kavicsiparai körének elkülönítése Közép-Európában. A típusok formailag illeszkednek az általános képbe, ám a mérettartomány szignifikánsan különbözik. Ennek felismerése számos további, a kultúrákra jellemző sajátosság azonosítását eredményezte. 


\begin{tabular}{|c|c|c|c|c|c|c|c|c|c|c|}
\hline & \multicolumn{2}{|c|}{ Bodrogkeresztúr } & \multicolumn{2}{|c|}{$\begin{array}{c}\text { Megyaszó } \\
\text { felszíni gyűjités }\end{array}$} & \multicolumn{2}{|c|}{ Pilismarót-Bitóc } & \multicolumn{2}{|c|}{$\begin{array}{c}\text { Ságvár } \\
\text { (Csongrádiné } \\
\text { Balogh 2000) }\end{array}$} & \multicolumn{2}{|c|}{$\begin{array}{l}\text { Mogyorósbánya } \\
\text { 1991-es ásatás }\end{array}$} \\
\hline & db & $\%$ & $\mathbf{d b}$ & $\%$ & $\mathbf{d b}$ & $\%$ & db & $\%$ & db & $\%$ \\
\hline \multicolumn{11}{|l|}{ hosszúsági csoportok } \\
\hline $10-19 \mathrm{~mm}$ & 46 & 4,50 & 29 & 7,61 & 12 & 3,65 & 21 & 9,81 & 15 & 6,02 \\
\hline $20-29 \mathrm{~mm}$ & 188 & 18,40 & 92 & 24,15 & 73 & 22,19 & 91 & 42,52 & 72 & 28,92 \\
\hline $30-39 \mathrm{~mm}$ & 324 & 31,70 & 90 & 23,62 & 102 & 31,00 & 71 & 33,18 & 97 & 38,96 \\
\hline $40-49 \mathrm{~mm}$ & 194 & 18,98 & 85 & 22,31 & 88 & 26,75 & 20 & 9,35 & 31 & 12,45 \\
\hline $50-59 \mathrm{~mm}$ & 64 & 6,26 & 38 & 9,97 & 31 & 9,42 & 5 & 2,34 & 23 & 9,24 \\
\hline $60-69 \mathrm{~mm}$ & 98 & 9,59 & 26 & 6,82 & 16 & 4,86 & 6 & 2,80 & 6 & 2,41 \\
\hline $70-79 \mathrm{~mm}$ & 43 & 4,21 & 11 & 2,89 & 2 & 0,61 & & & 3 & 1,21 \\
\hline $80-89 \mathrm{~mm}$ & 22 & 2,15 & 6 & 1,58 & 5 & 1,52 & & & 2 & 0,80 \\
\hline $90-99 \mathrm{~mm}$ & 22 & 2,15 & 2 & 0,53 & & & & & & \\
\hline $100-109 \mathrm{~mm}$ & 7 & 0,69 & & & & & & & & \\
\hline $110-119 \mathrm{~mm}$ & 7 & 0,69 & & & & & & & & \\
\hline$>120 \mathrm{~mm}$ & 7 & 0,69 & 2 & 0,53 & & & & & & \\
\hline összesen & 1022 & 100,00 & 381 & 100,00 & 329 & 100,00 & 214 & 100,00 & 249 & 100,00 \\
\hline átlaghosszúság (mm) & & 45 & & 41 & & 38 & & 31 & & 35 \\
\hline
\end{tabular}

szélesség/hosszúság csoportok

\begin{tabular}{lrrrrrrrrrrr}
$>100 \%$ & & & 3 & 0,81 & 13 & 3,95 & 15 & 7,01 & 7 & 2,81 \\
\hline $100-66 \%$ & 455 & 41,25 & 132 & 35,58 & 70 & 21,28 & 58 & 27,10 & 57 & 22,89 \\
\hline $66-50 \%$ & 204 & 18,50 & 96 & 25,88 & 84 & 25,53 & 54 & 25,23 & 55 & 22,09 \\
\hline $50-33 \%$ & 263 & 23,84 & 101 & 27,22 & 98 & 29,79 & 60 & 28,04 & 80 & 32,13 \\
\hline $33-25 \%$ & 112 & 10,15 & 28 & 7,54 & 38 & 11,55 & 17 & 7,94 & 32 & 12,85 \\
\hline $25-20 \%$ & 42 & 3,81 & 10 & 2,70 & 16 & 4,86 & 7 & 3,27 & 15 & 6,02 \\
$20-16 \%$ & 17 & 1,54 & 1 & 0,27 & 6 & 1,82 & 3 & 1,40 & 3 & 1,21 \\
\hline$<16 \%$ & 10 & 0,91 & & & 4 & 1,22 & & & & \\
összesen & $\mathbf{1 1 0 3}$ & $\mathbf{1 0 0 , 0 0}$ & $\mathbf{3 7 1}$ & $\mathbf{1 0 0 , 0 0}$ & $\mathbf{3 2 9}$ & $\mathbf{1 0 0 , 0 0}$ & $\mathbf{2 1 4}$ & $\mathbf{1 0 0 , 0 0}$ & $\mathbf{2 4 9}$ & $\mathbf{1 0 0 , 0 0}$ \\
\hline
\end{tabular}

3. táblázat. Eszközök és pengék metrikus adatai és arányszámai öt lelőhelyről. // Table 3. Metric values and ratios of tools and blades from five archaeological sites.

A paleolitikus kőeszközegyüttesek jellemzőinek matematikai kifejezésére a Bordes-féle indexek óta nem ismerek más, általánosan elterjedt módszert. Ez a bő félévszázados eljárás ma már idejétmúltnak minősül, bár minden későbbi kísérlet valamilyen módon erre vezethető vissza. Igaz, hogy maradéktalanul megbízható eredményeket még fénykorában is csak azokon a területeken hozott, amelyekre eredetileg is kidolgozták. Az újabb, egyes lelőhelyekre alkalmazott egyedi megoldásokkal a lényeg, az összehasonlíthatóság vész el.

Vértes László 1964-ben, a tatai monográfiában publikálta statisztikai rendszerét. A vértesszőlősi leletanyag feldolgozása során alkalmaztuk ennek egyes elemeit, ám bizonyosan jóval szikárabb végkövetkeztetésekkel, mint amikre az ásató juthatott volna.

A módszer első alkalmazásától kezdve vitát váltott ki, részben mert bonyolult, s talán kicsit öncélú, részben mert nem veszi figyelembe egy kultúra karakterét befolyásoló szubjektív tényezőket, részben mert a matematikai eredmények nem egyeztek a más úton szerzett tapasztalatokkal. Gábori M. recenziójában így látta: „A matematikai-statisztikai vizsgálat célja az, hogy megállapítsa, az ipar egyes jellegzetességei menynyire törvényszerüek vagy véletlenszerüek, - mi okozza az ipar, általában egy ipar specializálódását, a típusok állandósulását (standardizációját), s hogy az ipar egyes jellegzetességei, egzakt matematikai alapon, hogyan függnek össze egymással. ... Úgy látjuk, hogy ezeket az eredményeket egyszerúbb módszerekkel is elérhetjük, melyek szintén túljutottak a szubjektív tipológián." (Gábori 1966:125). Talán ezért nem is honosodott meg. E dolgozatban Vértes módszerének erôsen leegyszerúsített változatát alkalmaztam.

Nem kevés haszonnal járna a legfontosabb mennyiségi adatok (átlaghosszúság, laminarizáció mértéke, leütési szög stb) azonos módon történő kiszámítására egy mindenki által elfogadható protokoll kidolgozása. Bár teljes mértékben osztjuk Istvánovits E. véleményét, és kötelező előírásokkal, adminisztratív eszközökkel nem kívánjuk korlátozni az „újítások lehetôségét" (Istvánovits 2011:147), ám leletegyüttesek metrikus jellemzőinek reális és objektív összehasonlítására csak azonos módszerekkel nyert adatok alapján van mód. 


\section{Metrikus adatok}

A megvizsgált öt lelőhely eszközeinek és pengéinek hoszszúság-szélesség aránya változó, a klasszikus penge szekció (a szélesség kevesebb, mint a hosszúság fele, azaz 50\% alatt) 35,652,0\% között van: a gravetti entitás felső paleolitikus kultúra. A pavlovi eszközegyüttesek átlaghossza $10 \mathrm{~mm}$-rel nagyobb, mint a ságváriaké (3. táblázat). A többi, statisztikusan értékelhető mennyiségű leletanyag feldolgozása folyamatban van.

\section{Felhasznált irodalom}

Biró, K. T., Dobosi, V. T., 1991. Lithotheca - Comparative Raw Material Collection of the Hungarian National Museum. Budapest: Magyar Nemzeti Múzeum.

Bobak, D., Połtowicz-Bobak, M. 2010. Osadnictwo starszej epoki kamienia na połnocnym przedpolu Bramy Morawskiej. (Older Stone age settlement to the north of the Moravian Gate.) In: Gancarski, J. (ed.), Transkarpackie kontakty kulturowe w epoce kamienia, brazu i wczesnej epoce żelaza. Krosno: Ruthenus, 29-52.

Csongrádiné Balogh É. 2000. A ságvári késői felsőpaleolit lelőhely és környékéről előkerült leletanyag ismertetése. Somogyi Múzeumok Közleményei 14: 3-28.

Dobosi, V. T. 2000. Archaeological investigations at BodrogkeresztúrHenye. In: Dobosi, V. T. (ed.), Bodrogkeresztúr-Henye (NE Hungary), Upper Palaeolithic site. Budapest: Hungarian National Museum, 5-111.

Dobosi, V. T. 2001. Antecedents: Upper Palaeolithic in the Jászság region. In: Kertész, R., Makkay, J. (eds), From the Mesolithic to the Neolithic. Proceedings of the International Archaeological Conference held in the Damjanich Museum of Szolnok, September 22-27, 1996. Budapest: Archaeolingua, 177-191.

T. Dobosi V. 2006. Gravetti lelőhelyek Pilismarót környékén. Folia Archaeologica 52 (2005-2006): 21-48.

Dobosi V. T. 2011. Obsidian use in the Palaeolithic in Hungary and adjoining areas. Natural Resource Environment and Humans 1: 83-95.

Dobosi, V. T., Vörös, I., Krolopp, E., Szabó, J., Ringer, Á., Schweitzer, F. 1983. Upper Palaeolithic settlement in Pilismarót-Pálrét. Acta Archaeologica Academiae Scientiarum Hungaricae 35: 287-311.

Dobosi, V. T., Kövecses-Varga, E., Krolopp, E., Vörös, I., Magyar, I., Varga, I., Hertelendi, E. 1991. Upper Palaeolithic site at EsztergomGyurgyalag Acta Archaeologica Academiae Scientiarum Hungariae 43: $233-271$

Dobosi, V. T., Simán, K. 1996. New Upper Palaeolithic site at Megyaszó-Szelestető. Communicationes Archaeologicae Hungariae 1996: $5-22$.

Dobosi, V. T., Simán, K. 2003. Hont-Parassa III, Orgonás, Upper Palaeolithic settlement. Communicationes Archaeologicae Hungariae 2003: 15-29.

Gábori, M. 1964. Beiträge zum Paläolithikum des Donauknie-Gebietes. Acta Archaeologica Academiae Scientiarum Hungaricae 16: 171-186.

GáboriM.1966.VértesL.ésmunkatársai.Tata, einemittelpaläolithische Travertin-Siedlung in Ungarn. Archaeologiai Értesítő 93: 123-125.

Gábori-Csánk, V. 1984. Die Behausungsspuren von Dömös. In: Berke, H., Hahn, J., Kind, C.-J. (Hrsg.), Jungpaläolithische Siedlungsstrukturen in Europa. Kollokvium 8. - 14. Mai 1983 Reisensburg / Günz-burg. Urgeschichtliche Materialhefte 6, Tübingen: Verlag Archaeologica Venatoria, 251-256

Gáboriné Csánk V. 1984. A felső paleolitikum nyoma Budapesten. Budapest Régiségei 25: 7-14.
Istvánovits E. 2011. A nagyberuházásokat megelőző régészeti kutatások néhány tanulsága Szabolcs-Szatmár-Bereg megyében. In: Kővári K., Miklós Zs. (szerk.), „Fél évszázad terepen”. Tanulmánykötet Torma István tiszteletére 70. születésnapja alkalmából. Budapest: Magyar Tudományos Akadémia Régészeti Intézete, 141-149.

Łanczont, M., Wojtanowicz, J. 2010. Brama Przemyska a dostępność geograficzna i kulturowa regionu Karpat. (Przemyśl Gate and geographical and cultural accessibility of the Carpathian region.) In: Gancarski, J. (ed.), Transkarpackie kontakty kulturowe w epoce kamienia, brazu i wczesnej epoce żelaza. Krosno: Ruthenus, 9-28.

Lengyel Gy. 2009. A ságvári felső paleolit telep és a Kárpát-medencei gravetti kőnyersanyagai. In: Ilon G. (szerk), M MO VI. - Öskoros Kutatók VI. Összejövetelének konferenciakötete. Nyersanyagok és kereskedelem. Köszeg, 2009. március 19 - 21. Szombathely: Kulturális Örökségvédelmi Szakszolgálat-Vas megyei Múzeumok Igazgatósága, 223-231.

Markó, A. 2007. The Upper Palaeolithic Site at Szob. Folia Archaeologica 53: 7-22.

Minoru et al. 2011. Chronological study on the replace-ment of Neanderthal by modern human and the extraction of modern behavior. In: Hiroki Tanabe (ed.), The 4th Conference on Replacement of Neanderthal by Modern Humans. Okazaki, December 9, 2011. Abstracts.

Oliva, M. 1998. Gravettien východní Moravy. Acta Musei Moraviae, Scientiae sociales 83: 3-65.

Oliva, M. 2002.Využivaní krajiny a zdrojů kamenných surovin v mladém paleolitu českých zemí. Archeologické rozhledy 54: 555-581.

Priskin A. 2011. Jászfelsôszentgyörgy-Szúnyogos és -Székes-dülő felsô paleolit lelóhelyek pattintott köeszköz anyaga (tipológia és nyersanyag felhasználás). Szakdolgozat, Pécsi Tudományegyetem, kézirat.

Reményi L., Stibrányi M. 2011. Régészeti topográfia: ugyanaz másként. In: Kővári K., Miklós Zs. (szerk.), „Fél évszázad terepen”. Tanulmánykötet Torma István tiszteletére 70. születésnapja alkalmából. Budapest: Magyar Tudományos Akadémia Régészeti Intézete, 189-198.

Ringer, Á., Lengyel, Gy. 2008-2009. The Upper Palaeolithic site at Budapest Corvin-tér. Praehistoria 9-10: 205-211.

Simán, K. 1989. Hidasnémeti - Upper Palaeolithic site in the Hernád valley (Northeast Hungary). Acta Archaeologica Carpathica 28: 5-24.

Valde-Nowak, P. 2010. Karpacki tranzyt a interior w epoce kamienia. (The Carpathian Transit and Interior in the Stone Age.) In: Gancarski, J. (ed.), Trans-karpackie kontakty kulturowe $w$ epoce kamienia, brazu i wczesnej epoce żelaza. Krosno: Ruthenus, 53-60.

Valoch, K. 1987. Raw materials used in the Moravian Middle and Upper Palaeolithic. In: Biró, K. T. (ed.), Proceedings of the 1st International conference on prehistoric flint mining and lithic raw material identification in the Carpathian Basin. Budapest-Sümeg 20-22 May, 1986. Vol. 2, Budapest: Magyar Nemzeti Múzeum, 263-268.

Vértes, L 1964-1965.: Das Jungpaläolithikum von Arka in NordUngarn. Quartär 15/16: 79-132.

Vörös, I. 1982. Faunal remains from the Gravettian rein-deer hunters' campsite at Ságvár. Folia Archaeologica 33: 43-71.

Wilczyński, J. 2006. The Upper Paleolithic workshop at the site Piekary IIa sector XXII leyer 5. Sprawozdania Archeologiczne 58: 175-203.

Zandler K. 2011. Felső paleolit lelőhelyek az Ipoly men-tén. Neograd A Nógrád Megyei Múzeumok Évkönyve 34 (2010): 167-187. 